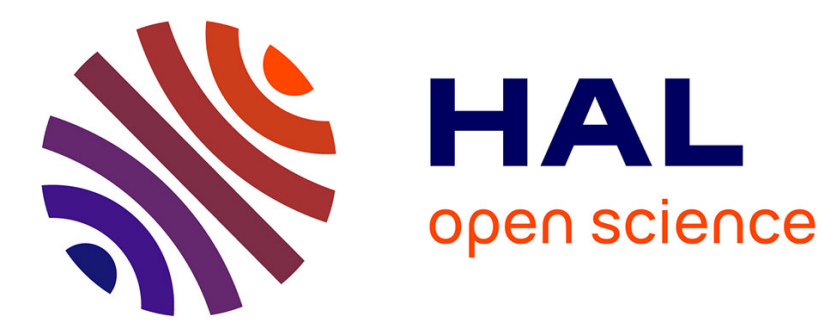

\title{
Veining and post-nappe transtensional faulting in the SW Helvetic Alps (Switzerland)
}

\author{
Giovanni Luca Cardello, Neil S. Mancktelow
}

\section{To cite this version:}

Giovanni Luca Cardello, Neil S. Mancktelow. Veining and post-nappe transtensional faulting in the SW Helvetic Alps (Switzerland). Swiss Journal of Geosciences, 2015, 108, pp.379-400. 10.1007/s00015-015-0199-7 . insu-01240702

\section{HAL Id: insu-01240702 \\ https://hal-insu.archives-ouvertes.fr/insu-01240702}

Submitted on 27 Nov 2021

HAL is a multi-disciplinary open access archive for the deposit and dissemination of scientific research documents, whether they are published or not. The documents may come from teaching and research institutions in France or abroad, or from public or private research centers.
L'archive ouverte pluridisciplinaire HAL, est destinée au dépôt et à la diffusion de documents scientifiques de niveau recherche, publiés ou non, émanant des établissements d'enseignement et de recherche français ou étrangers, des laboratoires publics ou privés.

\section{(c)(1)}

Distributed under a Creative Commons Attribution| 4.0 International License 


\title{
Veining and post-nappe transtensional faulting in the SW Helvetic Alps (Switzerland)
}

\author{
Giovanni Luca Cardello ${ }^{1,2} \cdot$ Neil S. Mancktelow ${ }^{2}$
}

Received: 27 March 2015/Accepted: 7 September 2015/Published online: 8 October 2015

(C) Swiss Geological Society 2015

\begin{abstract}
In the Rawil Depression of the south-western Helvetic Alps, oblique (normal plus dextral strike slip) faults are common but their relative age, regional role and the processes leading to their development are not yet fully determined. This field study establishes the orientation and distribution of these faults and associated veins, the fault geometries and kinematics, and the relationship between veining and faulting. Three post-nappe sets of faults can be distinguished on the basis of their strike: (1) NNW/NWstriking; (2) WNW/W-striking; and (3) WSW-striking ones. Faults sets (1) and (2) generally dip at moderate angle to the SW and typically develop domino-like structures, with a spacing of around $1 \mathrm{~km}$. Fault set (3) is steeper, the strikeslip component is larger, and it is directly associated with the main regional-scale branch of the Simplon-Rhône Fault. Although these faults are broadly coeval, there are clear examples of set (2) cross-cutting set (1), and set (3) crosscutting (1) and (2), which establishes, at least locally, a relative chronological succession. This transtensional faulting largely post-dates folding related to nappe formation because fold geometry can be matched across the obliquely crosscutting faults. Regional dextral-transtensional fault development is related to differential exhumation of the External Crystalline Massifs over the last 15-17 Ma, coeval with related movement on the Simplon-Rhône Fault. Locally
\end{abstract}

Editorial handling: S. Schmid.

Giovanni Luca Cardello

luca.cardello@univ-orleans.fr

1 ISTO-Institut des Sciences de la Terre d'Orléans, Université d'Orléans, 1A Rue de la Ferollerie, 45071 Orléans Cedex 2, France

2 Department of Earth Sciences, ETH Zurich, 8092 Zurich, Switzerland there is a transition from an initial more ductile mylonitic fabric to cataclasite, accompanied by brittle-ductile veining and intense pressure solution. This progressive embrittlement during faulting is due to exhumation and cooling during faulting, higher strain rates, or increased pore-fluid pressures. Faults of sets (1) and (2) developed across the brittleductile transition and may represent fossil seismogenic zones in rocks with high pore-fluid pressure, providing exposed examples of seismic faults in similar rocks currently active at depth north of the Rhône Valley.

Keywords Alps · Faults · Veins - Transtension · Brittleductile transition $\cdot$ Seismic activity

\section{Introduction}

The Helvetic Alps are one of the most studied fold-and-thrust belts in the world and are well known as the classic example where far-travelled "nappes" were initially recognized (Bertrand 1884; Schardt 1893; Lugeon 1902; Argand 1916; Heim 1920; Trümpy 1980; Masson 1980a, b; Ramsay et al. 1981, 1983; Dietrich 1989; Escher et al. 1993; Pfiffner 1993, 2011). However, although the nappe stack is certainly a firstorder feature characterizing the Helvetic Alps, late faults cross-cutting the nappe stack are also an important feature on the regional scale. Locally, veins and faults can occur with different orientations and characteristics, resulting in rather complex geometries that reflect different kinematics, magnitude of displacement and intersection patterns (Burkhard 1988; Huggenberger and Aebli 1989; Ustaszewski and Pfiffner 2008; Gasser and Mancktelow 2010).

The activity of the faults occurring in the Rawil Depression (Fig. 1) was already recognized as related to exhumation and cooling of the Helvetic Nappes (Schaub 


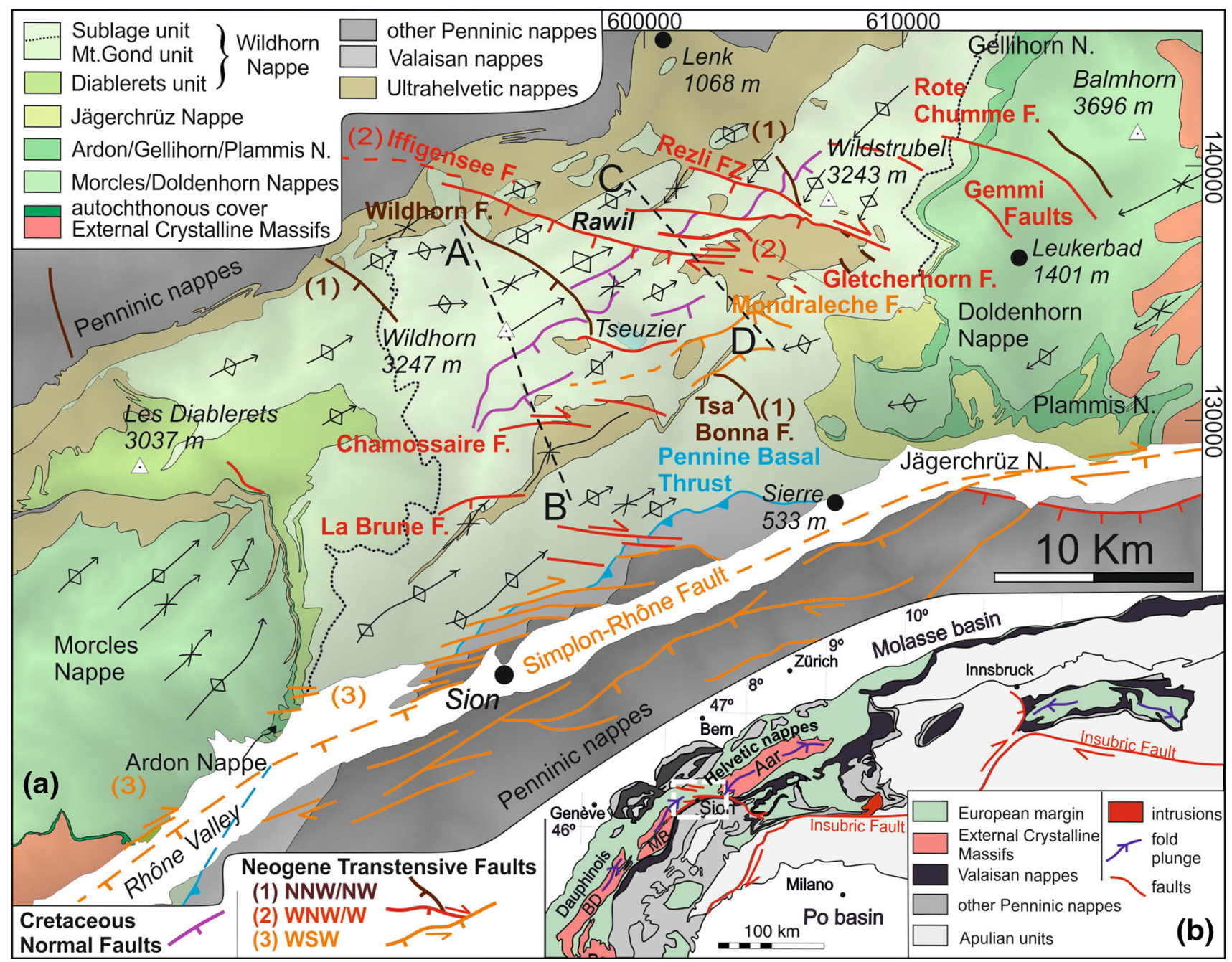

Fig. 1 a Tectonic map of the SW Helvetic Alps (modified after Steck et al. 1999). Names of faults are in red. b Inset tectonic map of the Alps (modified after Bigi and Carozzo 1992) with location of the study area (white dashed box)

1936; Ramsay et al. 1981). Petrologic studies indicate that peak metamorphic temperatures ranged from about 150 to $300{ }^{\circ} \mathrm{C}$, depending on the structural and geographic position (e.g. Bussy and Epard 1984; Burkhard 1988). These temperatures span the range typically taken to encompass the brittle-ductile transition (BDT) for carbonates in the upper crust. For a normal gradient of about $25^{\circ} \mathrm{C} / \mathrm{km}$ (Clark and Niblett 1956), these temperatures correspond to depths of around 6-9 km, which is commonly the hypocenter depth of major earthquakes for normal and strike slip faults in carbonates (e.g. Chiarabba et al. 2009; Chiaraluce 2012). According to Gasser and Mancktelow (2010), the internal structure of such faults changes with the rheological behaviour of each rock type that is cross-cut and incorporated into the fault zone, reflecting the different deformation processes involved. However, these authors recognized that there are still many open questions with regard to fault development in the Rawil Depression, in particular: (1) the cross-cutting relationships and relative age of different faults sets; (2) the absolute age of fault activity; (3) the contribution of ductile and brittle mechanisms to the amount of displacement accumulated on single fault planes; and (4) the role of fluids, and especially meteoric water, in the youngest structures. A coherent and complete documentation of the fault structure and kinematics was still missing. Important questions remained to be clarified in order to unravel how oblique-normal faults initiate and develop, to describe and understand the structural relationship between faulting and veining, and to establish the role of the Neogene faults in the development and exhumation of the Rawil Depression.

Oblique-normal faults are very common in the Rawil Depression but, according to published maps and profiles (Badoux et al. 1959; Badoux and Lombard 1962; Huggenberger and Aebli 1989; Gasser and Mancktelow 2010), these faults commonly lose displacement over short 
distances, especially on encountering more incompetent units (e.g. shales and marls), and do not cross-cut nappe contacts. From extensive field observation, a systematic chronological succession of tectonic events can be established from cross-cutting sets of faults and veins. These post-nappe events can be either relatively discrete (e.g. marked by cross-cutting faults and veins) or gradational, reflecting a progressive rotation of the stretching direction relative to the rock as recorded by gradual changes in the orientation of the vein tips and by associated, generally syntaxial, sigmoidal fibre growth within the veins (Durney and Ramsay, 1973; Ramsay and Huber 1983; Dietrich and Durney 1986; Mazzoli and Bucci 2003; Mazzoli et al. 2004). This field study aims to establish: (1) the orientation and distribution of these faults on the map-scale; (2) the fault geometries and kinematics; and (3) the relationship between veining and faulting. The overall objective is to unravel the relative timing and mode of faulting in this sector of the Alps. We consider the role of these obliquenormal faults in the regional structure and kinematics of this part of the Alpine arc and in particular their role in the development of the Rawil Depression. The current study is directly relevant to interpreting the very active seismicity currently recorded at depth below and north of the Rhône Valley (Pavoni 1980; Maurer et al. 1997; Kastrup et al. 2004; Frischknecht et al. 2005; Diehl et al. 2013), as well as in other carbonate-rich orogens (e.g. the Apennines of Italy; Cardello and Doglioni 2015). Many of these small earthquakes (magnitude $M_{\mathrm{L}}$ generally $\leq 3$ ) occurred at depths of $5 \mathrm{~km}$ or less and therefore within carbonate-rich sediments above the basement (cf. Burkhard 1988, his Fig. 10a). Finally, this contribution considers the fundamental mechanical question of how transtensional obliqueslip faults initiate and develop.

\section{Methods}

This study is based on detailed field work over a wide area, covering three regions characterized by a relatively homogeneous structural style (for more details see Cardello and Mancktelow 2014). These are, from north to south: (1) the 'frontal region' with very low metamorphic grade; (2) the 'high alpine region' that best preserves the cross-cutting relationships between the different fault sets; and (3) the 'southern region' that is defined by tight to isoclinal folds, lower greenschist facies metamorphic conditions, and an overprint by several different deformational phases.

Structural analyses were supported by mapping at $1: 10,000$ scale in the high alpine region and 1:25,000 in the lower southern region. In both regions, detailed work was undertaken to determine the geometric and kinematic relationship between veins and faults, and to establish a relative chronology for incremental stretching during the most recent part of the geological history of this orogen. Total fault displacement was calculated along several geological cross-sections, the most important ones being shown in profiles $\mathrm{AB}$ and $\mathrm{CD}$ profiles of Fig. 2, which is modified after Cardello and Mancktelow (2014).

The oblique-normal fault planes, together with the slip direction determined from slickenfibres (if discernible), were measured and subdivided on the basis of their geographic location. PBT-axes diagrams were calculated, providing the orientation of the principal incremental strain axes, which correspond to the principal stress axes $\left(\sigma_{1}, \sigma_{2}\right.$ and $\sigma_{3}$ ) if the material behaviour is close to isotropic. Values were calculated using the inversion approach of Sperner et al. (1993), with P representing the maximum, B the intermediate and $\mathrm{T}$ the minimum axis. Applications and limitations of this fault analysis (or "stress-inversion") technique are addressed in the discussion section.

The stratigraphic subdivision and unit names used in this manuscript are based on published tables of the Swiss Commission of Stratigraphy, as recently also used in Cardello and Mancktelow (2014). Outcrop locations are referenced using Swiss grid coordinates (e.g. 609986/140586 Easting/Northing).

\section{Geological background}

From the Mesozoic to the present day, the terrains belonging to the SW Helvetic Alps were affected by several tectonic events such as syn-rift extension, post-break-up extension, foreland extension, orogenic compression and orogen-parallel and orogen-perpendicular extension (Trümpy 1960, 1980; Ramsay et al. 1981; Burkhard 1988; Herb 1988; Huggenberger and Aebli 1989; Dietrich 1989; Escher et al. 1993; Seward and Mancktelow 1994; Kempf and Pfiffner 2004; Sue et al. 2007; Mohn et al. 2010). This long tectonic history has produced different generations of faults contributing to the development of the present day geometry.

In general, the Helvetic Alps (Figs. 1, 2) represent the deformed sedimentary cover deposited on the European continental crust from the Permo-Carboniferous to the Early Tertiary (Lugeon 1914-1918). Similar to what is observed elsewhere (e.g. Mohn et al. 2010; Cardello and Doglioni 2015), the Helvetic succession was repeatedly affected by syn-sedimentary normal faulting (e.g. GünzlerSeiffert 1941; Hänni and Pfiffner 2001). In our study area, the best-preserved evidence is for syn-sedimentary faults developed during the Cretaceous. These normal faults shown in Fig. 1 have considerable displacement (up to ca. $500 \mathrm{~m}$ ) and determine the distribution of re-sedimented facies in syn-sedimentary half-graben basins (Cardello and Mancktelow 2014). Most of the syn-sedimentary normal 
frontal region

high Alpine region

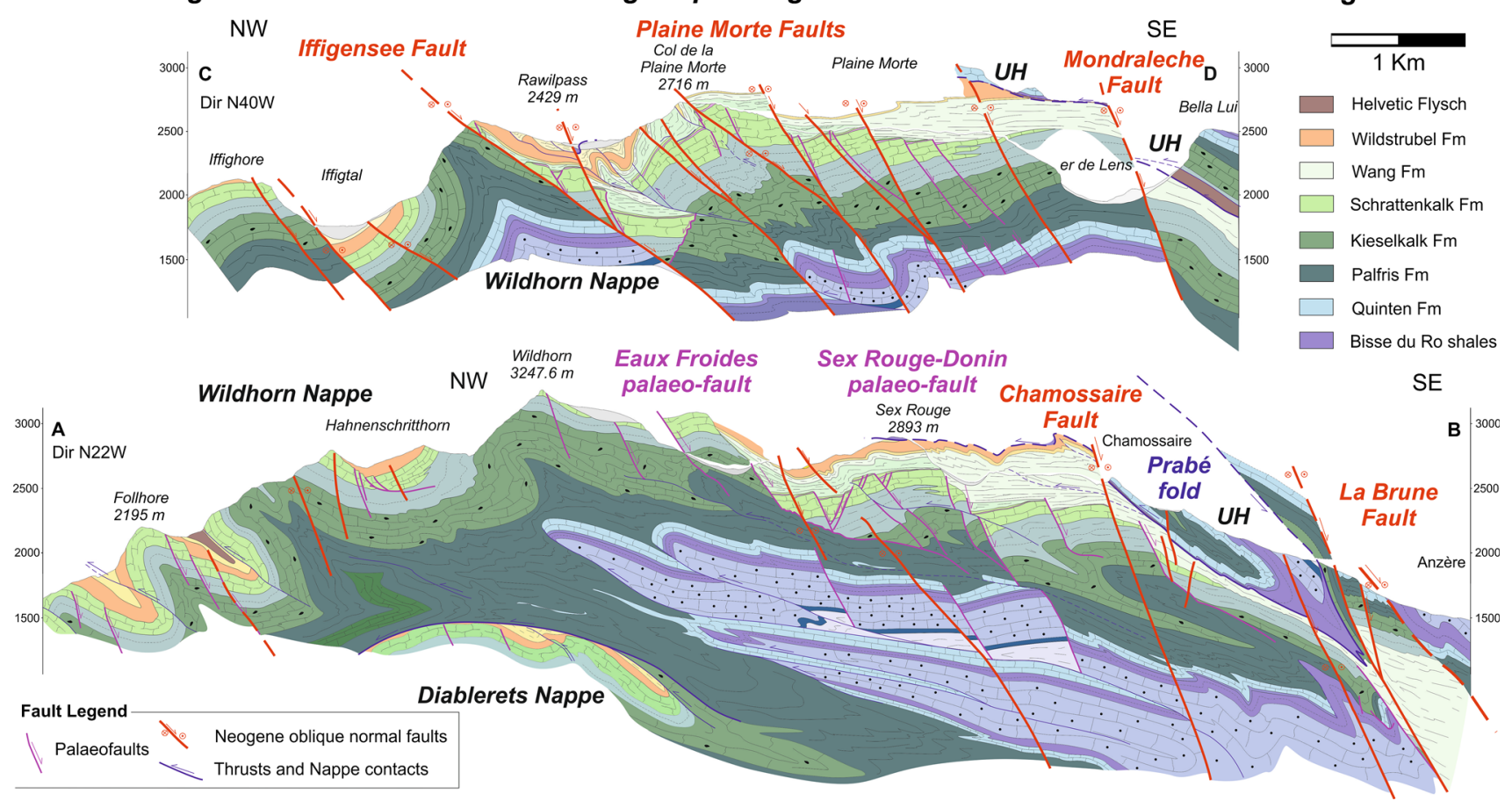

southern region

Fig. 2 Geological profiles (modified after Cardello and Mancktelow 2014), the trace of which are indicated on Fig. 1

faults strike SW-NE and are parallel to the fold axes (Günzler-Seiffert 1952).

In the Oligocene, the previously more distal Ultrahelvetic units overthrusted the (at that stage still unfolded) Helvetic domain over a distance of some $100 \mathrm{~km}$ (Jeanbourquin 1994). After this event, two major stages of further convergence can be distinguished (Heim 1920; Ramsay et al. 1983; Burkhard 1988, 1993; Maurer et al. 1997; Pfiffner 2009). Thin-skinned tectonics during the first stage produced folds with a wavelength on the order of 10's to 100 's of metres, associated with thrusts at the base of the nappes defined by 10's of kilometres displacement. Within each nappe, internal displacement on minor thrusts was less important (on the order of 10's of metres). On a large scale, the resultant nappe stack is composed of two main nappe complexes defined by a common palaeo-geographic origin and structural history. From top to bottom and, in their original palaeo-geographic position, from south to north, these are generally referred to as the Penninic and Helvetic units. As a result of this nappe stacking, the Helvetic sequence itself has been repeated several times in the Rawil Depression (Trümpy 1960; Steck et al. 1999). From the lowest (para-) autochthonous to the higher and more allochthonous, these nappes are the Morcles and Doldenhorn, the Diablerets and Gellihorn, the Wildhorn and the Ultrahelvetic nappes (Fig. 1). Each unit shows internal stratigraphic heterogeneity as well as minor thrusts and associated folds of smaller scale, indicating NW-verging thrusting. According to Crespo-Blanc et al. (1995) and Kirschner et al. (2003), the nappes were emplaced in the time period from ca. 32 to 15 Ma. In the Rhône Valley, the Wildhorn and Penninic units (Sion-Courmayeur zone; Burri 1969) were metamorphosed up to lower greenschist facies, with a rapid transition to anchizone facies within the first kilometres NW of Sion (Bussy and Epard 1984; Burkhard and Kerrich 1988). The second stage of compression started in the Early to Middle Miocene and was associated with cooling, probably related to the progressive exhumation of the Alps (Burkhard 1988; Vernon et al. 2008; Sternai et al. 2012). New U-Th/He zircon age data presented in Cardello (2013) show that after the emplacement of the Wildhorn Nappe, the Diablerets and Doldenhorn nappes in the Rawil Depression were cooled to temperatures of ca. $200{ }^{\circ} \mathrm{C}$ in the time period between ca. 17 and $15 \mathrm{Ma}$. The nappe stack was up-domed and folded on a large scale (ca. $10 \mathrm{~km}$ across), with an amplitude that indicates crustal-scale thrusting (Pfiffner 2009). The axial depression of this antiform has its structurally lowest point in the Rawil pass region (i.e. the Rawil Depression; Lugeon 1914-1918; Heim 1920; Burkhard 1988; Gasser and Mancktelow 2010). As a secondary effect of differential basement uplift, the Rawil Depression began to form after the Early to Middle Miocene but continued its development until the Pliocene $(\sim 3.5 \mathrm{Ma})$, when most of the up-doming was complete (Cardello et al. 2015). The different structural style of the two major compressional events (i.e. nappe stacking and broad post-nappe up- 
doming) reflects a gradual change from thin- to thickskinned tectonics, which, according to the geological profile across the Sanetsch Pass area of Pfiffner (2009), progressively involved deeper thrusting within the basement. This deep thrusting was linked to the ongoing deformation of the outer arc of the Western Alps (Maurer et al. 1997; Sue et al. 2007).

Veins are a common feature within the Helvetic nappes (e.g. Ramsay et al. 1981; Dietrich et al. 1983; Burkhard 1988) and provide indispensable information on the progressive change in the incremental stretching direction (e.g. Durney and Ramsay 1973; Casey et al. 1983). Burkhard and Kerrich (1988) distinguish three different sets of veins: pre-, syn- and post-tectonic according to their involvement in the nappe-emplacement and further deformation. In the current study, none of the veins are considered to be strictly post-tectonic because they still reflect the incremental strain at the time of their formation. Several comprehensive studies have considered the transition from ductile deformation to brittle faulting in the Pennine nappes south of the Rhône Valley (Bistacchi and Massironi 1998, 1999; Bistacchi et al. 2000; Bistacchi and Massironi 2000; Bistacchi et al. 2001; Champagnac et al. 2003, 2004; Grosjean et al. 2004; Scheiber et al. 2013). Fault studies north of the Rhône Valley have mainly focused on the neotectonics (Hoffmann et al. 2004; Ustaszewski et al.2008) and the potential relationship of faults to active seismicity (Pavoni 1980; Maurer et al. 1997; Kastrup et al. 2004; Frischknecht et al. 2005; Diehl et al. 2013). From vein relationships, Franck et al. (1984) established a succession of stretching events in the Sanetsch pass area of the Rawil Depression, relating the youngest NW-striking veins to present-day seismicity, the $\mathrm{N}$-striking veins to nappe-emplacement and the NE-striking veins to syn-sedimentary faulting. During the latest stage of deformation, younger transverse faults were exhumed to the surface in the footwall of the Simplon-Rhône Fault, associated with differential uplift of the Mont Blanc/Aiguilles Rouges and Aar/Gastern External Crystalline Massifs (Gubler et al. 1981; Glotzbach et al. 2011) and development of the Rawil Depression.

\section{Results}

\subsection{The nappe stack: fold and thrust events}

In the 'high alpine region', two main folding events are discernible whereas in the 'southern region' up to four deformational phases related to folding can be recognized $\left(D_{1-4}\right)$. These phases refold the Ultrahelvetic Basal Thrust and hence post-date it. The $\mathrm{D}_{1}$ fold axes trend (W)SWE)NE and form tight to isoclinal folds on a regional scale (e.g. Drône anticline, Prabé syncline; Badoux et al. 1959).
This event was called the 'Prabé phase' by Burkhard (1988) and is associated with overthrusting at the base of the overturned limbs (e.g. the basal thrust of the Diablerets Nappe). The SW-striking $\mathrm{D}_{2}$ folds are quite asymmetric and are associated with the main cleavage, which is pervasive in the more shaly units and spaced in the more competent ones. $\mathrm{D}_{2}$ folds are generally upright and quite open in the frontal and 'high alpine region' but tighter in the 'southern region'. Burkhard (1988) refers to the $\mathrm{D}_{2}$ event as the 'Trubelstock phase'. As evident from overprinting relationships in the outcrop just north of Icogne (600707/125864), the Penninic Basal Thrust cross-cuts the $\mathrm{D}_{1-2}$ structure but is later folded (for details, see Cardello 2013, pp. 77-83). D 3 kink folds typically show a box-fold geometry with variably oriented but steep axial planes. These kinky $\mathrm{D}_{3}$ folds are often associated with ductilebrittle shear zones and crenulation cleavage as a precursor to faulting during ongoing deformation. Traces of an additional SW-striking $\mathrm{D}_{4}$ phase characterized by box folds with a steep NW-dipping axial plane occur in places in the 'southern region'.

The late Neogene to Quaternary structures represent the latest evolutionary steps in this transition from ductile to brittle behaviour and from thrusting and folding to postnappe transtensive fault disruption of the nappe stack. The latest of these events contribute to the final form of the Rawil Depression. In fact, the structural depression (i.e. the place where the highest nappes are preserved), is shifted ca. $5 \mathrm{~km}$ to the west with respect to the axial depression, where the fold axes and stretching lineations are horizontal (e.g. Gasser and Mancktelow 2010). This suggests that the more brittle faults dissected the former structure during its late formation, down-throwing units to the SW. For simplicity, we will refer to the Rawil Axial Depression just as the Rawil Depression.

\subsection{Vein orientation and distribution}

Veins are very common in the Rawil area and developed throughout the deformation history of the Helvetic Nappes, particularly in the Wildhorn Nappe where we focussed our research. Veins are especially concentrated in the Nummulitenkalk limestones (in the old terminology), in the pelagic limestones of the Seewen Fm, and in the limestone beds of the Schrattenkalk and Quinten Fms. Veins are distinguished here on the basis of their mode of formation and degree of deformation (Fig. 3). They can occur as: (a) deformed veins that are folded, cross-cut by stylolites, compacted, sheared or boudinaged (or any combination of these); (b) veins parallel to bedding or foliation; (c) sheared veins parallel to faults or within calc-mylonitic shear zones; (d) veins in en-échelon arrays within 'brittle-ductile' shear zones related to either subvertical or sub-horizontal 
Fig. 3 a Boudinaged vein parallel to bedding and (top right) detail of sheared vein. Gemmi region (613492/ 138570). b Sheared en-echelon vein sets along ductile-brittle shear zones. Gemmi region (613477/138537). c Sheared veins within a fault zone. Gemmi region (609449/ 138760). d SSE-dipping calcitequartz veins crosscutting SWdipping syntaxial quartz-calcite veins. Rezlisee, $2250 \mathrm{~m}$ (604043/138657). e Counterclockwise (CCW) rotation of dip direction of veins, from WSW for set (2) to SSE for set (3). Since there are only two sets in this outcrop, their relative numbering has been changed in accord with regional observations. The progressive nature of this rotation can be seen from the tips of vein set (3). Crans Montana, $1470 \mathrm{~m}$. (605557/130697) f Crosscutting vein relationships in a calcareous level of the Globigerina Marls Fm. Arrows indicate stretching directions, numbers the order of stretching, indicating a $\mathrm{CCW}$ rotation. Rawilpass, 2405 m. (601759/ 134774). g Poles to veins (extensional fractures) from the whole study area. Note that some of the SW-striking veins are possibly of Cretaceous age. h Calcite fibre direction in the veins from the whole study area
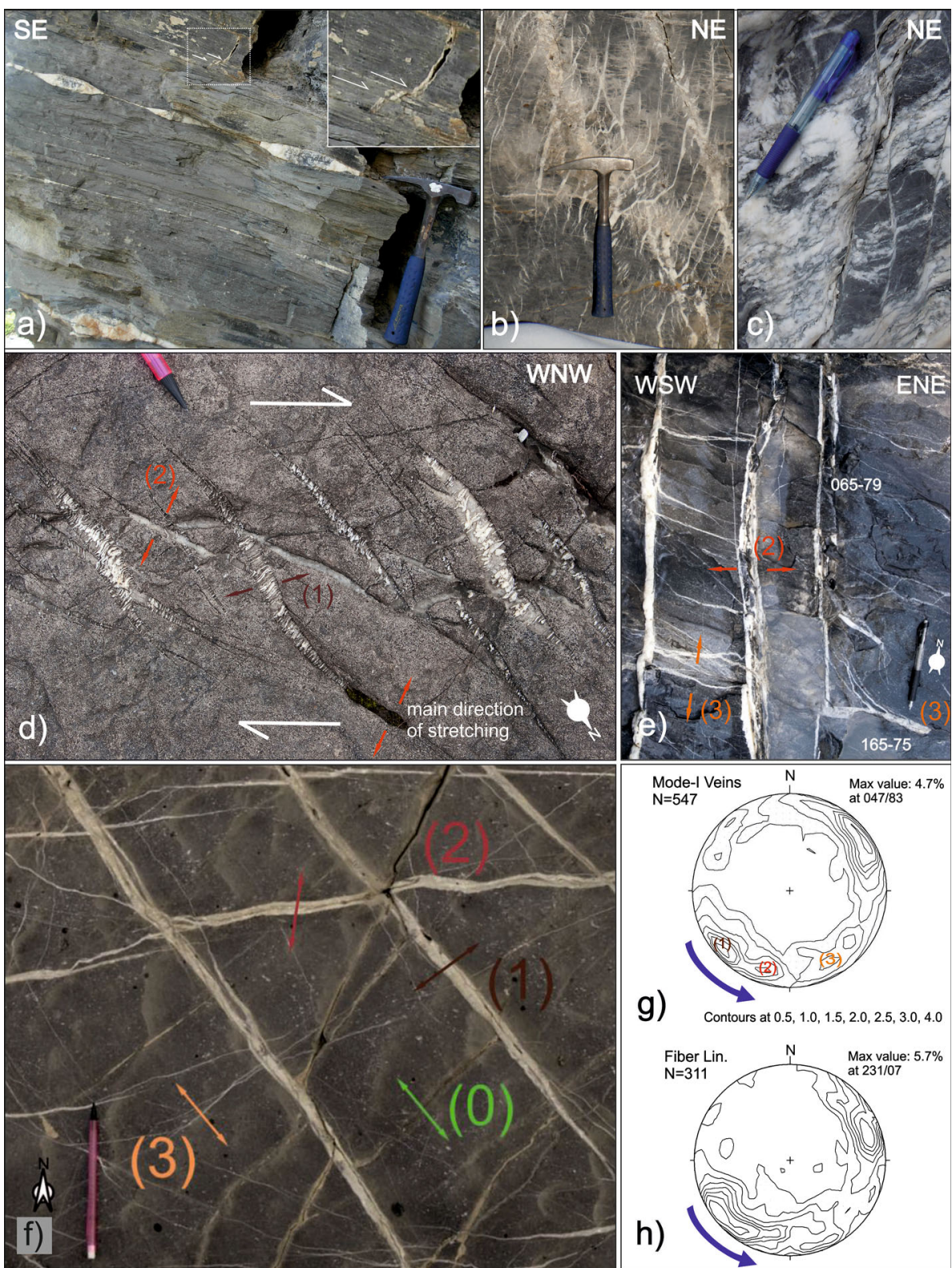

g)

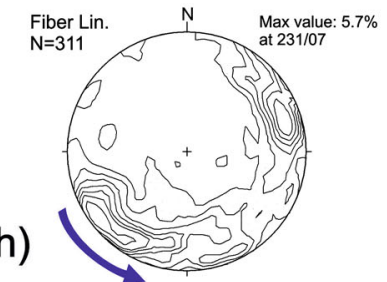

shortening (i.e. within either normal or strike-slip zones, respectively); (e) mode-I fractures infilled by calcite and quartz (veins) that may be widespread and occur far from the principal fault zones, reflecting the regional history of incremental strain. This last category of veins can be separated into three distinct sets (Fig. 3) on the basis of their opening orientation, as defined by the direction perpendicular to the walls and the direction of syn-tectonic fibres within the veins: (1) NNW/NW-striking; (2) WNW-striking; and (3) SW-striking. Calcite dominates in veins wider than a few millimetres with quartz sometimes found concentrated at the walls, depending on the composition of the country rocks. Although these veins may have been significantly tilted during post-nappe up-doming and their orientation changed, the distinctive characteristics still allow the different sets to be distinguished. Veins usually cross-cut bedding and foliation at a high angle and are commonly not discernibly folded, sheared or evidently deformed after their final stage of opening. A progressive increase in the number and size of veins is observed in the more competent lithologies approaching the main damage zone of oblique-slip faults, which implies increased fluid circulation toward the fault zones (Figs. 3b-c, 4). Far from the faults, veins record the regional stretching direction during their opening and infilling by new mineralization. In contrast, close to the faults, their orientation and shape can be influenced by the interconnection of veins and mineralization on fault planes, by rotation in the fault damage 

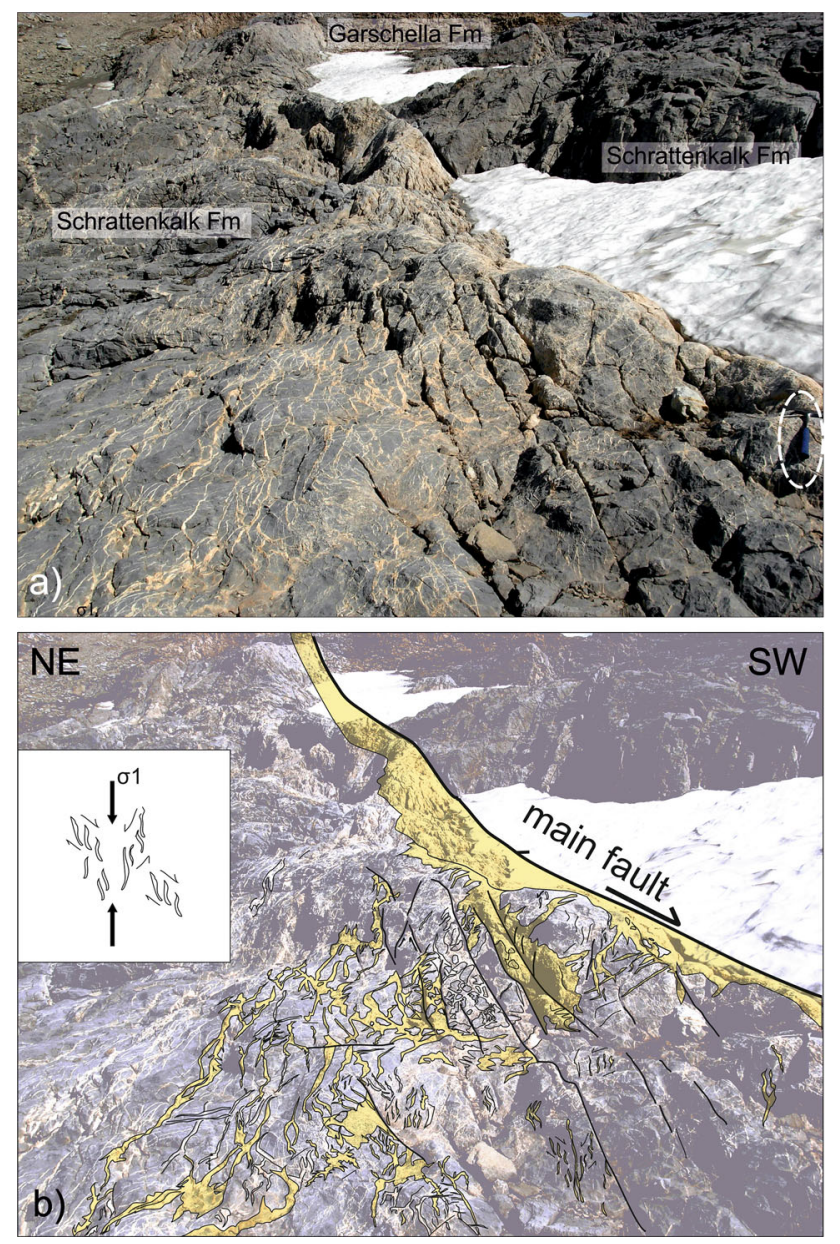

Fig. 4 Veining and faulting on a moderate displacement fault at Col de la Plaine Morte (600842/135762). En-échelon brittle-ductile shear zones are gradually interconnected approaching the fault core. Scale given by the hammer within the dashed ellipse, in the bottom right of a. Calcite-rich areas are indicated in yellow in $\mathbf{b}$

zone and by stress refraction effects, so that the currently measureable opening direction can deviate from the regional trend.

In general, veins far from faults are less affected by local perturbation of the strain due to co-genetic faults or preexisting structures. Veins of type (a) and (b) have been deformed during nappe emplacement whereas those of type (c) and (d) formed later in the structural history. The distinction between syn- and post-folding veins is made with reference to the main foliation-forming event associated with nappe emplacement and not with regard to the subsequent broad up-doming. Veins of type (c) and (d) are coeval with the later transtensive faulting, during updoming of the Aar and Mt. Blanc massifs and development of the Rawil Depression.

The normal and strike-slip end-members of set (d) represent a system of ductile-brittle transtensional structures whereby the principal extensional axis $\sigma_{3}$ is well defined but $\sigma_{1}$ and $\sigma_{2}$ may flip or progressively change their position around a girdle. The sketch of Fig. 5 illustrates this combination of the two end-member cases. In this example, conjugate brittle-ductile shear zones also occur
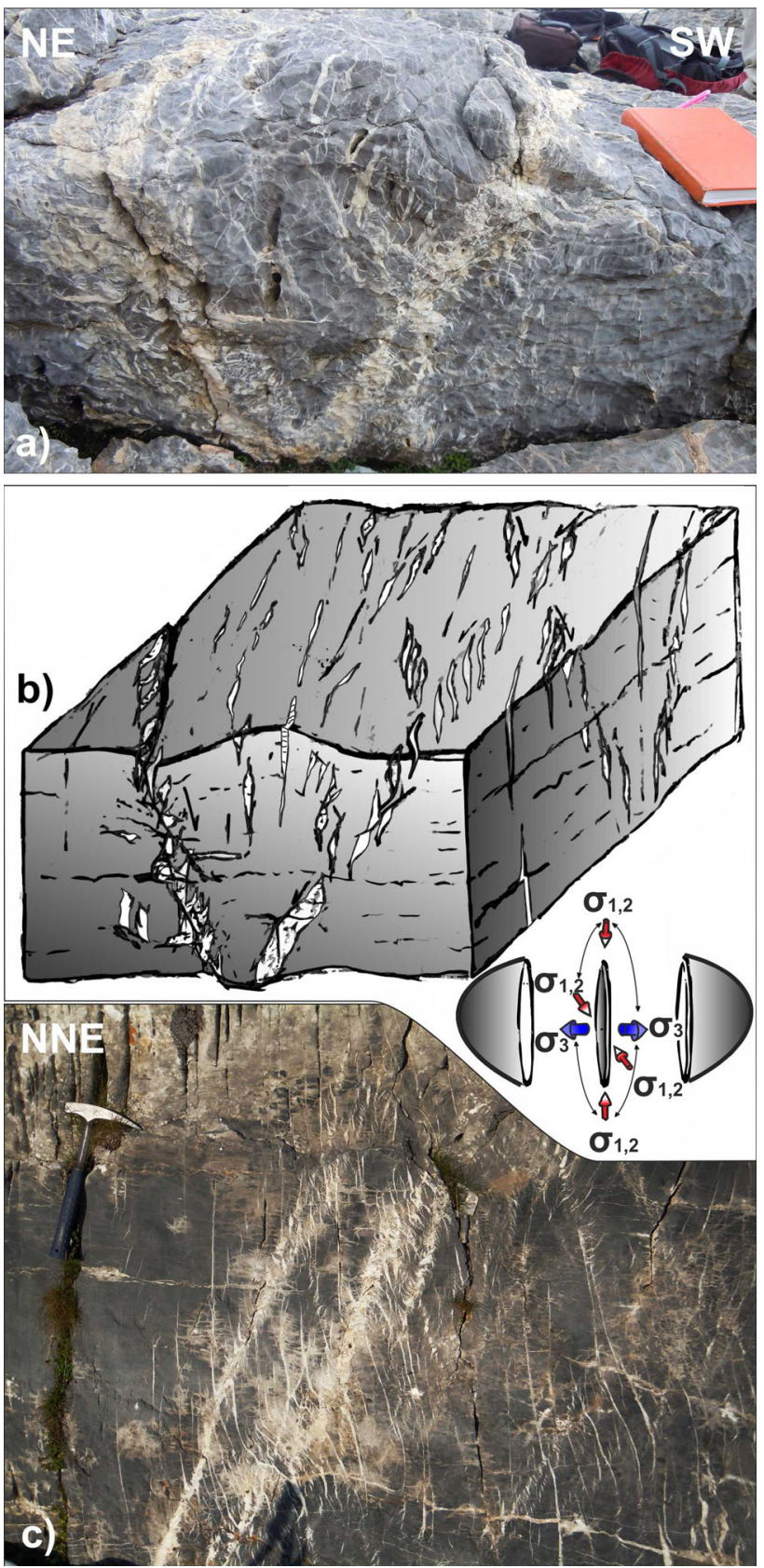

Fig. 5 a Conjugate en-échelon vein system associated with subhorizontal pressure-solution planes parallel to bedding. On the left there is an example of fault initiation. Weisshornlücke (602677/ $136443,2820 \mathrm{~m})$. b 3D sketch of oblique-normal ductile-brittle shear and faulting taking photo a) as an example. c $2 \mathrm{D}$ example of fault initiation and shearing of veins within conjugate ductile-brittle shear zones. As the viewing direction is near-perpendicular to strike, the apparent dip of bedding is sub-horizontal. Gemmipass (613477/ 138537) 
and are defined by arrays of syntaxial veins that are developed at an angle of $20^{\circ}-30^{\circ}$ to the mode-I veins.

In the veins of category (e), calcite fibres in the central part of the vein may be oblique to the vein walls (syntaxial veins) and the tips of the veins can diverge from the strike of the central part of the veins, representing the latest stages of progressive vein opening. This implies, at least locally, progressive rotation of the incremental stretching direction relative to the vein (or vice versa). Away from the fault damage zones, the cross-cutting vein relationships and the change in tip orientation and of sigmoidal fibres indicate a progressive, generally counter-clockwise relative rotation of the stretching direction, from WSW toward S to SSE for the post-folding veins. The initial and most important WSW-stretching direction is effectively parallel to the fold axes and, on a regional scale, is orogen-parallel.

\subsection{Post-nappe fault geometry: relative timing and mode of faulting}

The relative age of the post-nappe faults is established by cross-cutting relationships, as shown for example in Fig. 6. These faults are younger than the Alpine fold-and-thrust structures related to nappe stacking and, in general, they also cross-cut rather than reactivate the syn-sedimentary Cretaceous faults that typically strike SW-NE, parallel to the fold axes (Cardello and Mancktelow 2014). Little or no reactivation of pre-existing faults was observed. This is particularly evident in the Plaine Morte area, where synsedimentary Cretaceous normal faults appear to have been only very weakly reactivated as normal-oblique faults during the Neogene. When present, reactivation is concentrated in the more fine grained units (i.e. Amden Fm),

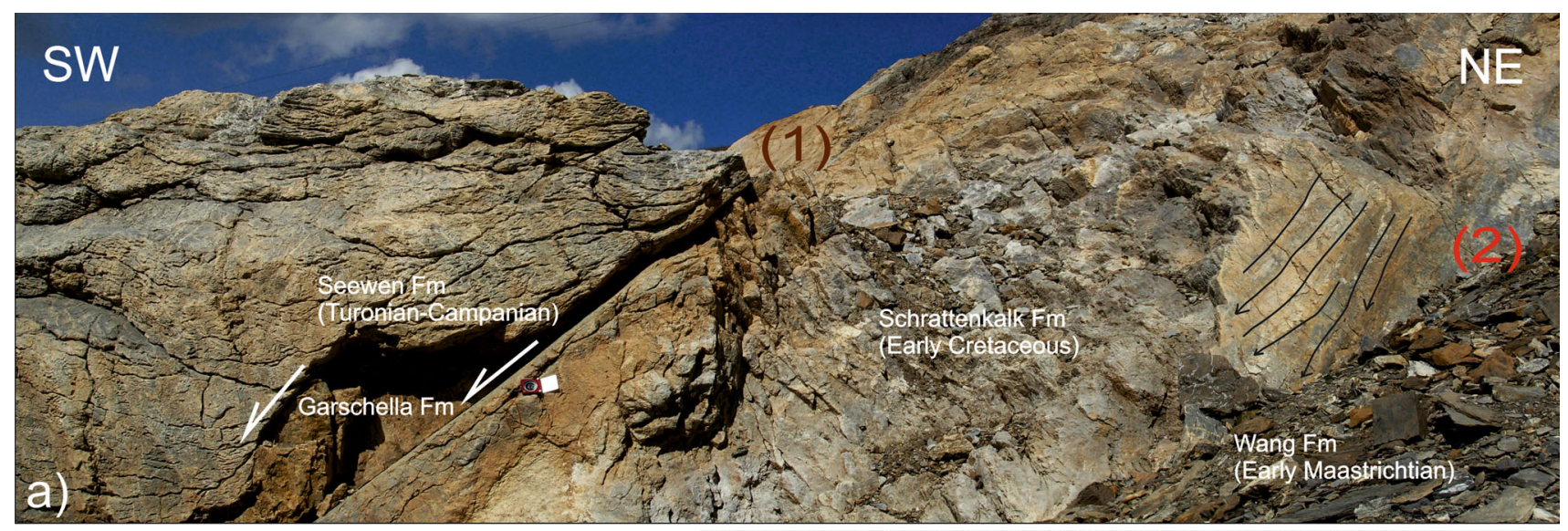

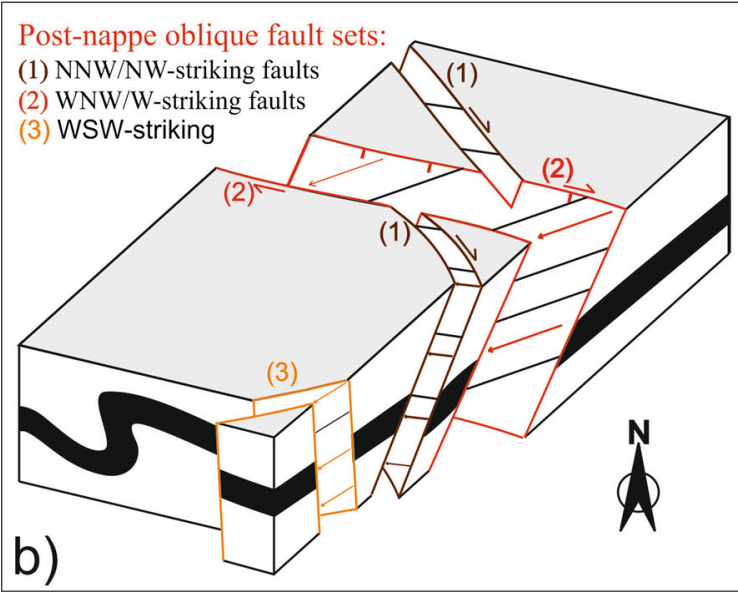

Fig. 6 Cross-cutting fault relationships. a Fault set (1) is cross-cut by (2), with the main slickenfibre direction on this plane indicated by thin black lines with arrowheads. Wildstrubelhütte, (602508/136659). For scale, a square bright compass can be seen immediately below the white arrow of fault set (1). b Schematic block diagram, showing the distinction between the three post-nappe oblique fault sets (1), (2) and

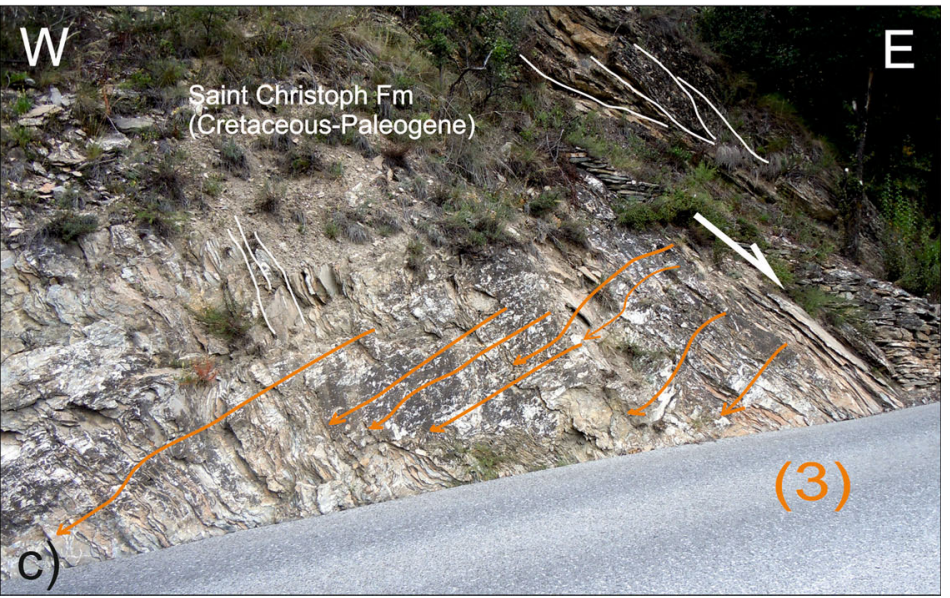

(3). c Example of fault structure in the Rhône Valley (592461/ 120452) belonging to fault set (3). In black and white, main foliation of foot- and hanging wall, respectively; orange arrows mark the slickenfibre directions, giving top to the SW shear; the white arrow indicates the normal dip-slip component of displacement 
where S/C type structures have been observed. At the Rawil pass, the Cretaceous Eaux Froides Fault (Cardello and Mancktelow 2014) is dismembered by Neogene strikeslip to oblique-normal faults, without discernible reactivation.

The post-nappe faults can be separated into three distinct sets on the basis of their strike orientation: (1) NNW/NWstriking; (2) WNW/W-striking; (3) WSW/SW-striking.

\subsubsection{NNW/NW-striking fault set (1)}

Fault set (1) is locally represented by isolated faults that are not cross-cut or associated with fault set (2) (Fig. 1), even though they usually occur in the same area. This fault set is variable in dip, from quite low-angle to steep, but generally dips at a moderate angle to the SW and typically develops bookshelf structures as, for example, in the Tsa Bonna area.

\subsubsection{The Tsa Bonna Fault The Tsa Bonna Fault} (Fig. 7a-b) is a normal-oblique fault with modest displacement occurring within the Late Jurassic Quinten Fm of the Ultrahelvetic nappes. The fault structure is defined by a complex fabric with a well-defined fault core generally characterized by cemented and fractured cataclasites, discrete slip surfaces with slickenfibres, and fault gouge.

The fault length is up to a few hundred metres and the displacement is on the order of 50-70 m. Both footwall and hanging wall preserve mylonites and deformed marbles that only occur within the fault zone, with a thickness of ca. $0.5 \mathrm{~m}$ to either side. Closer to the fault plane, the mylonites are progressively re-crystallized and brecciated. Mylonites are cut by discrete minor slip surfaces with fault kinematics consistent with the deviation of the foliation away from the principal slip surface, indicating oblique-normal faulting to the WSW. Locally, in lenses preserved between minor slip surfaces within the mylonites, $\mathrm{C}^{\prime}$ and other microstructures indicate the opposite sense of shear (top to the ENE). This could be related to local compression experienced by the mylonites during the embrittlement of the mylonitic shear zone/fault. The occurrence of cross-cutting slip surfaces within the newly formed fault core and within the resultant lenses during the ductile to brittle transition can generate micro-thrusts and related kinematic indicators with a sense of shear opposite to the overall movement on the fault plane (Fig. 7b).

\subsubsection{The Wildhorn Fault The Wildhorn Fault (Fig. 7c,} d) is a normal-oblique fault that accumulated an offset of about $300 \mathrm{~m}$ on a $3 \mathrm{~km}$ fault length, cross-cutting the whole Cretaceous sequence and transecting both pre-existing Cretaceous syn-sedimentary faults and Alpine thrusts. The fault structure exposes calc-mylonites in the footwall where the lithology is composed of platform-
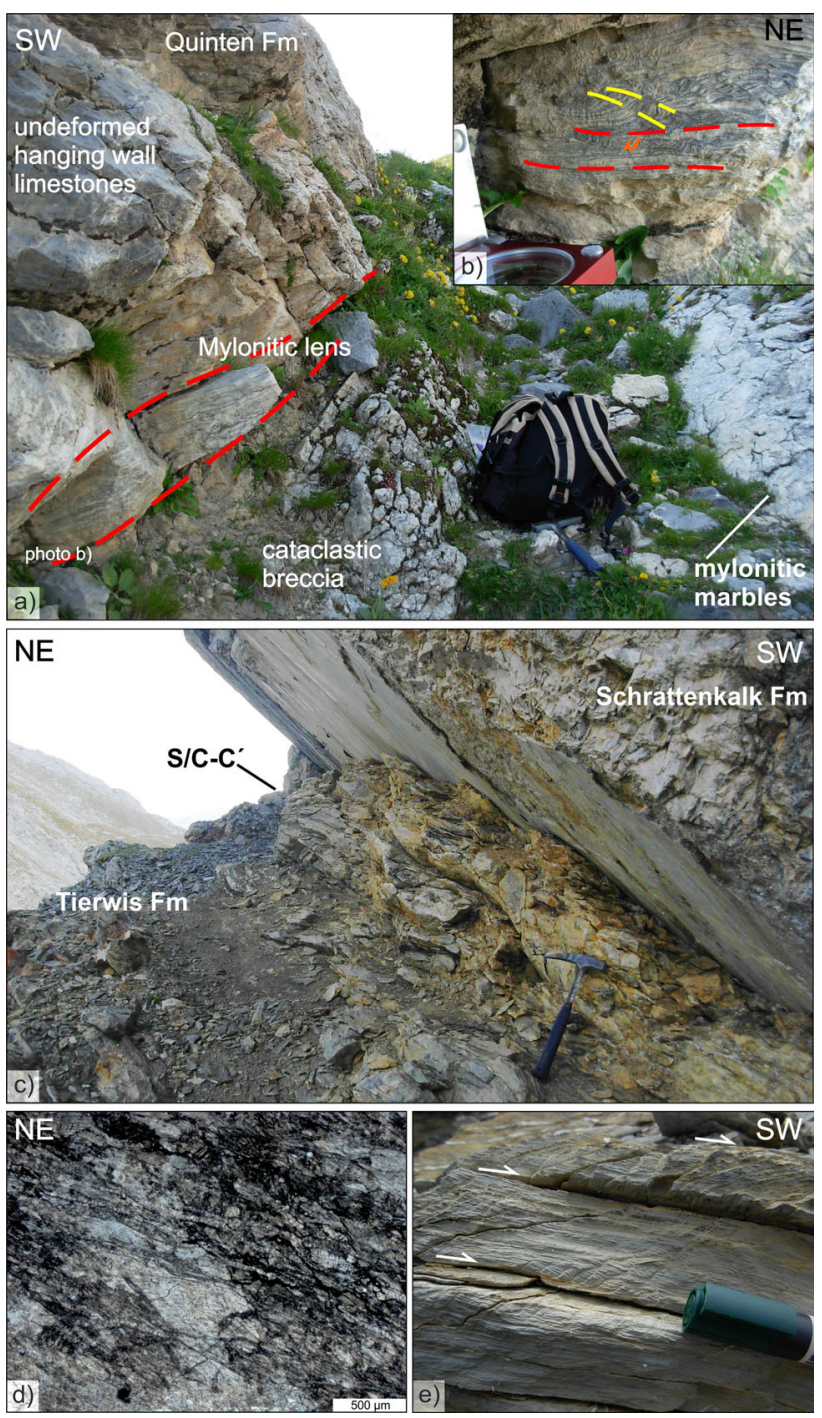

Fig. 7 Fault zone core from the Tsa Bonna Fault (604094/132545, $2450 \mathrm{~m}$ ). a From left to right, transition from undeformed bedrock into the fault zone. b Mylonitic foliation preserved on either side of the fault zone and as lenses in the cataclastic breccia. c Wildhorn Fault. Fault core structure with marly ductile units in the footwall and mylonitic to more brittle/cataclastic limestones, separated by a discrete late slip surface. d Thin section photograph of a reworked mylonite collected in the footwall of the Wildhorn Fault (697307/134298) with common pressure solution planes (dark levels), twinned calcite and gradually finer grain size of clasts toward the top-right. e Amden Fm marls (Upper Cretaceous) progressively sheared and transposed with a top to the SW sense. Rawilpass region (601465/137287)

derived limestones, whereas marls of the Tierwis Fm form $\mathrm{S} / \mathrm{C}$ structures. The fabric of the mylonites is clearly reworked by pressure-solution. The fault contact with the Schrattenkalk Fm in the hanging wall is discrete and is marked in places by $0.5-2 \mathrm{~cm}$ thick calcite mineralization. At Wildhornjoch, where the fault juxtaposes limestone against limestone, the resultant cataclasites are invaded by newly precipitated calcite. Widespread re-crystallization, 
twinning and pressure-solution are the main features observed in thin section (Fig. 7d). More to the east in the Rawilpass area, the Amden Fm marls show a progressive strain gradient approaching the fault zone (Fig. 7e).

\subsubsection{The Gemmipass region East of the Wildstrubel in} the Gemmipass region, several steep faults with obliquenormal to strike-slip kinematics cross-cut the nappe boundaries between the Doldenhorn, Gellihorn and Wildhorn nappes. This cross-cutting relationship is evident both from field mapping and from satellite images of the region. The faults often occur as conjugate sets with a small opening angle of $20^{\circ}-25^{\circ}$ or less, with the corresponding principal compressive stress axis, $\sigma_{1}$, trending to the NW. Their fault length is extraordinary long, up to $3 \mathrm{~km}$ in some cases, compared with their generally modest displacement $(<50 \mathrm{~m}$, commonly $<10 \mathrm{~m})$. Fault structure is mainly represented by thick calcite mineralization (up to $1-1.5 \mathrm{~m}$ thick) and cataclasites. Depending on the lithology, the cataclasites involved can be either matrix- or cement-supported. More calcareous units develop fault cores rich in euhedral (and often coarse-grained) crystals of calcite and accessory quartz. These faults have been reported as possible candidates for recent post-glacial tectonics in the area (Ustaszewski et al. 2008; Ustaszewski and Pfiffner 2008). The most prominent structure, the Rote Chumme Fault, is some $1.5 \mathrm{~km}$ long and offsets the boundary between the Doldenhorn and Gellihorn nappes, where maximum displacement is about $150 \mathrm{~m}$. This fault loses displacement to the north but its continuation can be traced further into the Wildhorn Nappe. Within some of the cross-cut formations, faults from the Gemmipass region are richer in veins (e.g. Quinten Fm), whereas in other, generally shaley or marly horizons, the response is more ductile (e.g. Dugny Fm). Within the Quinten Fm of the Wildhorn nappe, the fault at location 612072/140943, for example, is characterized by an asymmetric fault core defined by ca. $1 \mathrm{~m}$ thick matrixsupported cataclasite organized in lenses, delimited by sharp boundaries, and constituted of rounded clasts of different dimensions and composition. Riedel planes cross the fault core in the more competent lithologies. Close to the sharp contact to the footwall, the clasts are composed of reworked cataclasite and calcite. For some 3-4 m from the fault core, the damage zone is defined by lenticular-shaped bodies of highly re-crystallized limestones of the Quinten Fm that are particularly affected by veins. In other places (e.g. the Rote Chumme Fault at 613146/140843), a sharp slip surface accompanied by about 1-2 m thick cataclasite separates the damage zone from rock that is only affected by the background deformation. Along fault traces, the number of veins associated with the principal slip surface and the subsidiary faults depends on the lithologies involved, but overall the number of veins decreases away from the fault. In more detail, for the well-exposed example at 612072/140943, Aalenian marls of the Dugny Fm involved within the fault core are affected by pressuresolution and by less common veining when compared to the Quinten Fm limestones of the hanging wall. There is no cataclasite, showing that deformation is dominantly ductile in the more shaley footwall, whereas it is more brittle in the limestone-dominated hanging wall, where more fluid circulation was also clearly involved.

\subsubsection{WNW/W-striking fault set (2)}

Fault set (2) is the most important and representative of the region between the Wildstrubel area in the east and the Sanetsch pass in the west. The main structures are the Rezli Fault Zone and the Iffigensee Fault (Burkhard 1988; Huggenberger and Aebli 1989; Fig. 8). From Fig. 8, it is evident that the oblique-normal faults cross-cut and displace earlier fold-and-thrust structures. In particular, inherited Cretaceous palaeo-faults and related palaeoescarpments (Fig. 8a) are sharply cross-cut, as well as folds and thrusts related to development of the nappe-stack (Fig. 8b). The Rezli Fault Zone was recently mapped and described by Gasser and Mancktelow (2010). Several parallel or synthetic branches depart from the main slip surfaces of these major set (2) faults. NE-striking faults (set 1) of modest displacement (up to $20 \mathrm{~m}$ ) also occur bounded by parallel slip surfaces of set (2). This is well exposed at the western side of the Wildstrubeljoch Glacier (Fig. 8d; 602549/136594). More to the SW, the Chamossaire Fault is well exposed in a polished creek outcrop, allowing the fault structure and evolution on this steep E-W striking structure to be investigated in detail.

\subsubsection{The Iffigensee Fault and Rezli Fault Zone The} Iffigensee Fault (Burkhard 1988; Huggenberger and Aebli 1989) is characterized by a well-defined principal slip surface with a fault length of about $12 \mathrm{~km}$ and displacement on the order of $1.25 \mathrm{~km}$. Although the fault structure is complex in detail, the fault zone is generally represented by a quite localized area of deformation that cross-cuts, without significant reactivation, both Cretaceous syn-sedimentary faults and Alpine folds and thrusts, and thereby affects a range of lithostratigraphic units. Despite the diverse rheological behaviour of these different lithologies that were affected by the fault zone, the fault itself is not refracted or deviated but simply passes through the preexisting layering or anisotropy without significant change in orientation. Mylonitization and recrystallization are typical processes affecting the relatively pure shallowwater limestones of the Schrattenkalk Fm where they are involved in the fault zone. Mylonites at the contact are up to $1-1.5 \mathrm{~m}$ thick and, as in the Tsa Bonna area, are mostly 
Fig. 8 Iffigensee Fault at the Rawilpass. a Transverse view. b View along strike. c Iffigensee Fault west of Mittaghorn (699558/137056). Reworked mylonites occur within lenses in the fault core. d Fault plane dipping $80^{\circ}$ toward $201^{\circ}$ with an older slickenline set that shows oblique-normal kinematics and a younger one with effectively dip-slip normal movement. Weisshornlücke $2902 \mathrm{~m}$ (602653/136635)
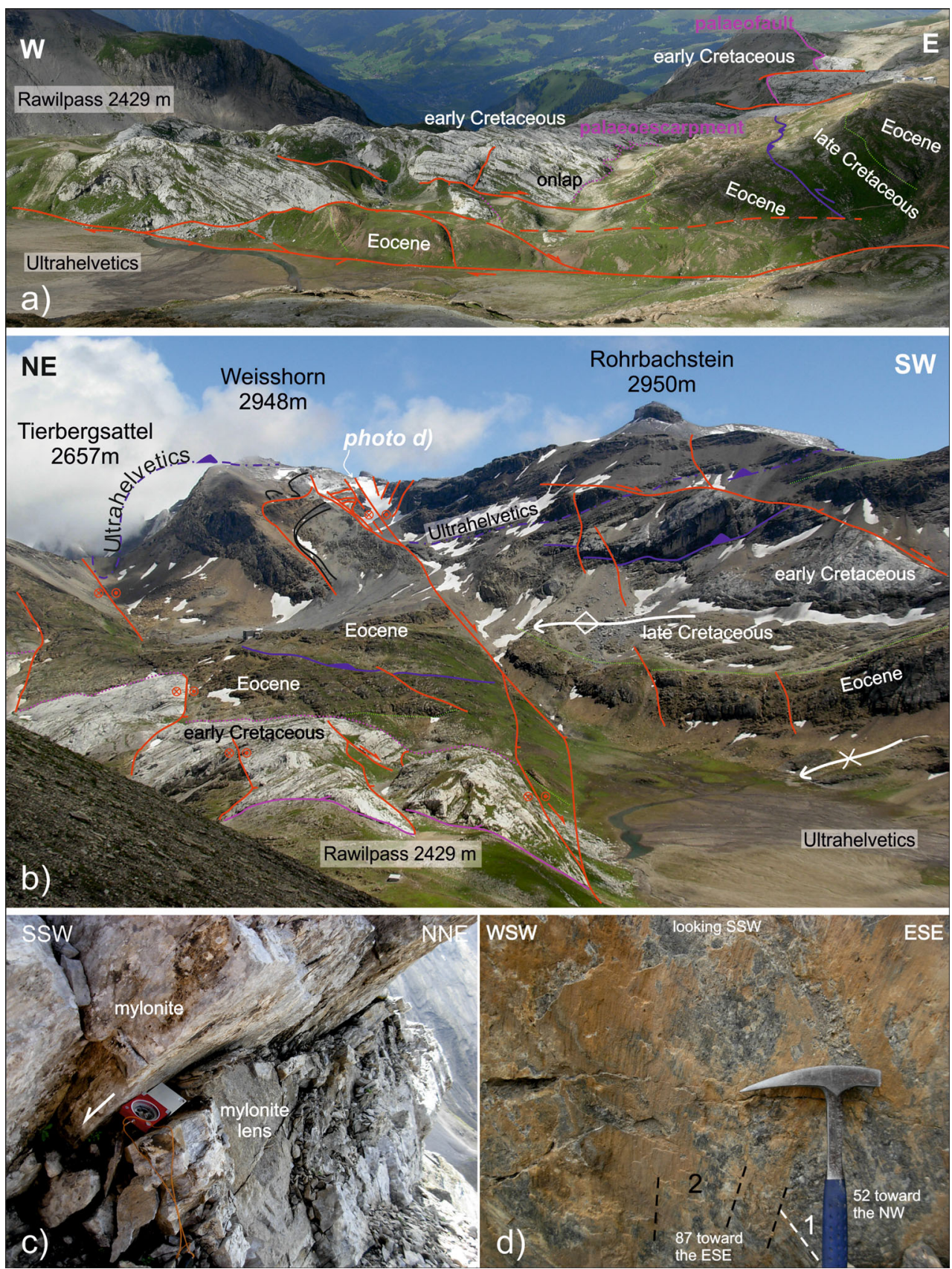

preserved within lenses bounded by discrete slip surfaces in the fault core. Pelagic limestones and marls form S/C structures, whereas the Eocene sandstones of the Wildstrubel Fm are affected by fractures, rare veins and subsidiary faults. Micritic limestones of the Quinten Fm in the Ultrahelvetic nappes are crossed by several subsidiary faults of modest displacement that are characterized by massive veining concentrated mostly on the fault plane. Veins are distributed in an en-échelon pattern with the same implied kinematics as that recorded by slickenfibres on the fault plane that cross-cuts them, indicating that the veins developed as a precursor to more localized faulting.
More to the east, the Wildstrubel area is also crossed by the Rezli Fault Zone (Gasser and Mancktelow 2010), with a cumulative displacement of about $0.7 \mathrm{~km}$, and by the Gletscherhorn Fault (Fig. 1). On the principal branch of the Rezli Fault Zone, an initial mylonitic fabric within limestones of the Schrattenkalk Fm is reworked by subsequent cataclasitic overprinting. The mylonitic fabic is crossed by folded veins and pressure-solution planes normal to the direction of movement, with mylonitic clasts reworked within the cataclasite. Both the Iffigensee and the Rezli Faults sharply cross-cut structures related to fault set (1) (e.g. Fig. 6) 


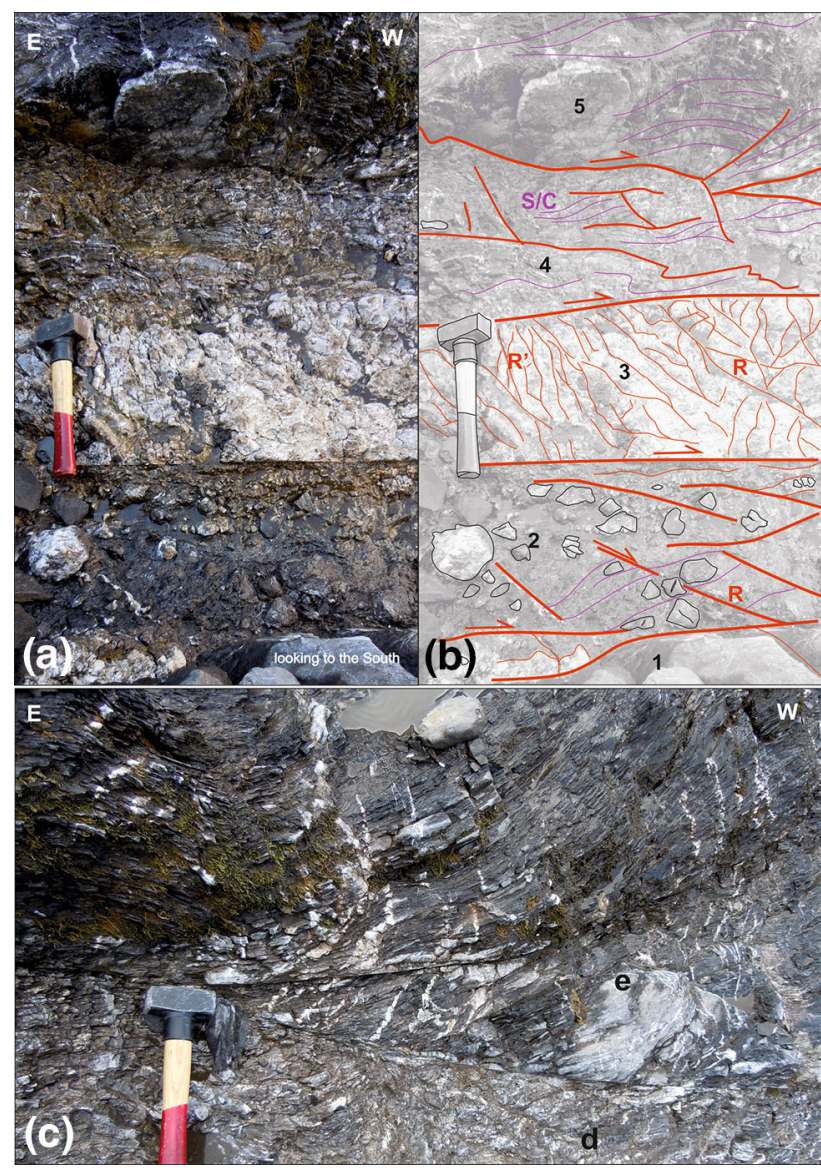

Fig. 9 Chamossaire Fault (595497/129647, 2310 m). a-b Details of the fault geometry: 1 Fractured and veined Tierwis Fm (Lower Cretaceous marly limestones); 2 Foliated and fractured cataclasite with clasts of Tierwis and Schrattenkalk Fm; 3 Fractured and recrystallized breccia of Schrattenkalk Fm (Lower Cretaceous platform limestones); 4 Riedel fractures and asymmetric folds in foliated cataclasite indicating dextral shear, with repeated faulting and more ductile shear; 5 Foliated Wang Fm marls (Lower Maastrichtian). c Detail of zones $4-5$ at the northern limit of the fault core

4.3.2.2 The Chamossaire Fault The Chamossaire Fault is an EW-striking, steeply dipping oblique-normal fault with an important dextral strike-slip component. The fault length is ca. $1.2 \mathrm{~km}$ and the horizontal displacement ca. $100 \mathrm{~m}$. At the well-exposed location shown in Fig. 9 (595497/ 129647), the footwall consists of: (a) little deformed to veined limestones of the Tierwis Fm (Fig. 9b, zone 1), which are crossed by sporadic, $2-3 \mathrm{~cm}$ thick veins of calcite immediately adjacent to the sharp contact with the fault core; (b) fractured, veined and recrystallized limestones of the Schrattenkalk Fm, which are progressively dragged into the fault core, and (c) marly limestones and marls of the Wang Fm that are affected by S/C structures close to the main slip surfaces. The fault core is $1-1.5 \mathrm{~m}$ thick and involves several different lithologies. It can be divided into four zones characterized by different structure and therefore rheological behaviour during the fault activity. In Fig. 9, zone (2) is characterized by foliated and fractured cataclasite containing clasts of Tierwis and Schrattenkalk Fms, obliquely cross-cut by Riedel fractures (R). The contact with the zone (3), which consists of highly fractured and recrystallized monomict breccia of Schrattenkalk Fm, is sharp. Zone (4) is a finer grained cataclasite (compared to zone 2), characterized by a well-developed foliation affected by Riedel fractures and asymmetric folds. The contact with zone (5), which is represented by well foliated marls crossed by folded veins and truncated by pressure-solution seams, is sharp but folded (Fig. 9b, c). The folding of Riedel fractures and discrete slip surfaces within the fault core shows that plastic creep played an important role even for generally brittle conditions. The sense of shear implied by the "ductile" structures is in agreement with the kinematic indicators on the main slip surface, indicating a consistent geometric and kinematic regime during continued movement along the Chamossaire Fault.

\subsubsection{WSW/SW-striking fault set (3)}

Fault set (3) occurs mainly along the northern flank of the Rhône Valley (Fig. 1), where the fault planes are steep and show a dominant dextral strike-slip component (fault set (4) of Gasser and Mancktelow 2010). These steeply SEdipping oblique-normal faults are locally associated with steep chevron folds, suggesting a transition from more distributed ductile folding to localized faulting during their development. Geographically and kinematically, they are closely associated with the main regional-scale branch of the Simplon-Rhône Fault that trends along the Rhône Valley. At Mont d'Orge close to Sion, WSW-striking faults have a mean lateral displacement around $600 \mathrm{~m}$ and fault length of 1-2 km. When not covered by vineyards, the fault structure is characterized by steep anastomosing surfaces mineralized by calcite and quartz, commonly precipitated as slickenfibres. The fault plane is in places determined by en-échelon coalescence of parallel, more EW-oriented segments, with contractional stepovers (e.g. Peacock and Sanderson 1995; Pennacchioni and Mancktelow 2013). Locally fault sets (1) and (2) are cross-cut by fault set (3), indicating that, at least in the Rhône Valley between Sion and Sierre, (3) is the youngest set. Fold axes there are $\mathrm{N}-\mathrm{S}$ trending, possibly because of rigid-block counter-clockwise back-rotation between Riedel faults of set (3) related to the overall dextral strike-slip movement (Fig. 1). Faults can be also associated with cataclasites, resulting in a well-structured fault core, such as observed on the Mondraleche and La Brune Faults (Figs. 1, 2). These dextral oblique-slip faults have an accumulated down-dip normal component of about $1 \mathrm{~km}$, implying that a great part of the relative displacement due to uplift of the high alpine region has been localized on these structures. 


\subsection{Fault kinematics and stress history}

Fault kinematic analyses were conducted across a wider region of the Rawil Depression, although the number of faults is much higher, and thus the statistics better, in the area between the Rawil pass and the Wildhorn, and in the Rhône Valley. Fault inversion PBT-diagrams for each area are shown in Figs. 10 and 11 and results are listed in Table 1 . The minimum stress ( $\mathrm{T}$ ) axis consistently plunges shallowly to the NE throughout the depression. In contrast, the maximum $(\mathrm{P})$ and intermediate $(\mathrm{B})$ principal stress axes are more distributed along a girdle perpendicular to this constantly oriented $\mathrm{T}$-axis, suggesting that the difference in magnitude between $\sigma_{3}$ and $\sigma_{2}$ was minimal. Locally, this is reflected in the tendency for the orientation of $\sigma_{3}$ and $\sigma_{2}$ to switch. For example, in the Sublage and Gemmi areas, the intermediate axis is steeply dipping to the NE and the faults are mainly characterized by strike slip kinematics. At the Lake of Tzeusier, the measurements indicate extension to the SSW, which can be related to the Mondraleche Fault (or Mondarelesse Fault; cf. Günzler-Seiffert 1952).
Despite the lack of sufficient data for determining any robust statistics, in two areas (i.e., Rawilpass and St-Léonard North, Tables 2, 3; Fig. 11), the population of faults was sufficient to subdivide the database into two distinct clusters. The orientation of the minimum stress $(\mathrm{T})$ axis in the main cluster plunges to the $\mathrm{SW}$, which is parallel to the extension direction reported in many areas in Table 1 . In the second cluster belonging to the faults excluded from the main cluster, the position of $\mathrm{P}$ - and $\mathrm{B}$ - axes is poorly constrained and the two axes overlap in orientation, but the position of the T-axis is well defined, trending toward the WNW. The $\mathrm{P}$-axis generally plunges to the $\mathrm{NW}$ at a variable angle and, as in the case of the Rawilpass, tends to spread around a steep NW-striking great circle. From the fault cross-cutting relationships, this fault set cluster could belong to an earlier stage of post-nappe faulting and veining, possibly related to fault and vein sets (1), whereas the main cluster could reflect the stress field related to fault and vein sets (2). Fault set (3) is well represented by the SSE-dipping faults in the Rhône Valley, which are consistently in a suitable orientation for dextral strike-slip reactivation.

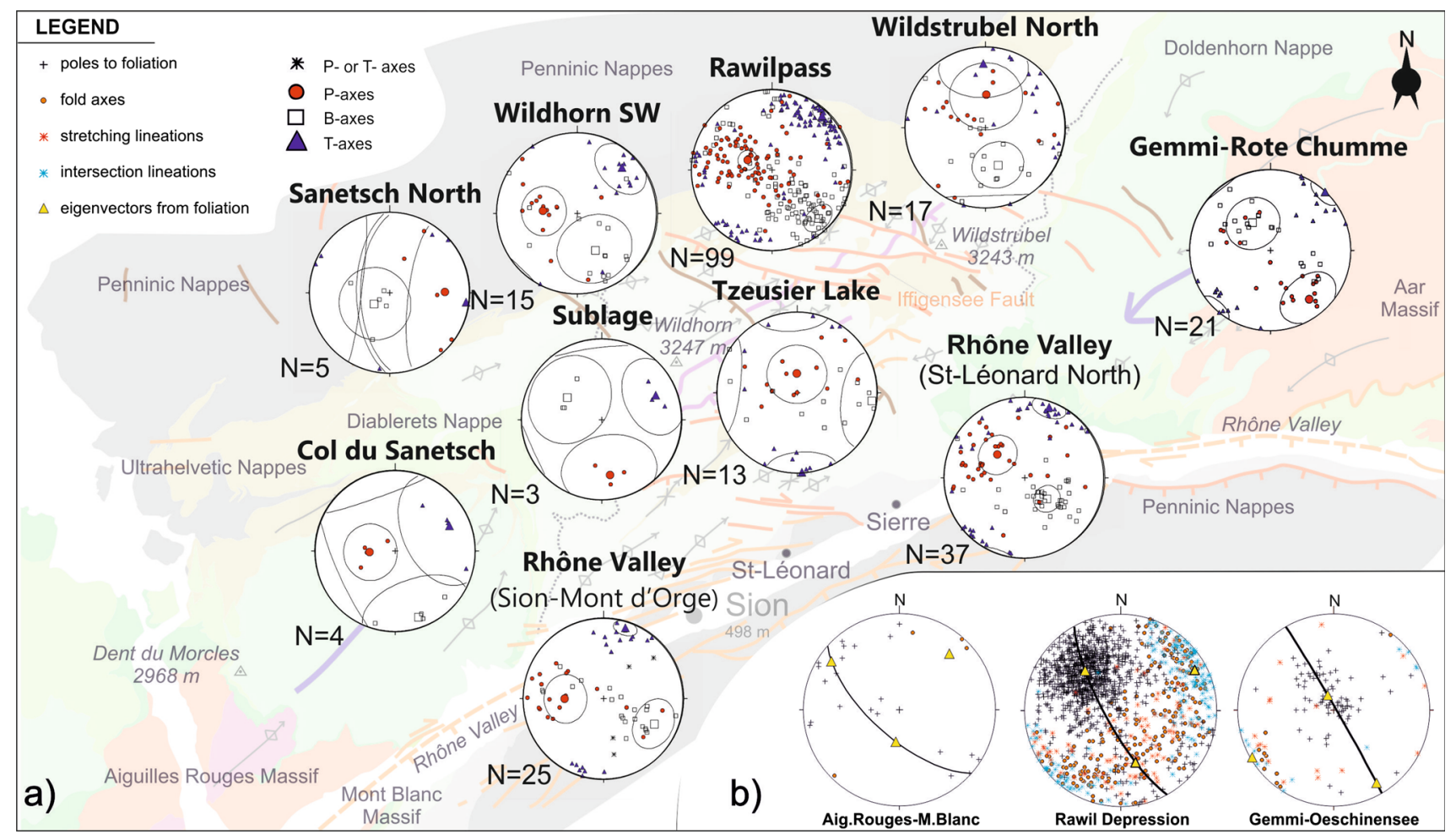

Fig. 10 Regional distribution of PBT axes compared with foliation and fold axes and stretching lineation data a Lower-hemisphere equal-area projection plots of structural data measured in the study area (cf. Fig. 3g, h). b Plot of poles to foliation, fold axes, stretching and intersection lineations, with the eigenvectors calculated for the poles to foliation indicated as yellow triangles. Data are plotted separately for the western (Aiguilles Rouges/Mont Blanc), central ("Rawil Depression") and eastern (Gemmi-Oeschinensee) parts of the Rawil Depression 


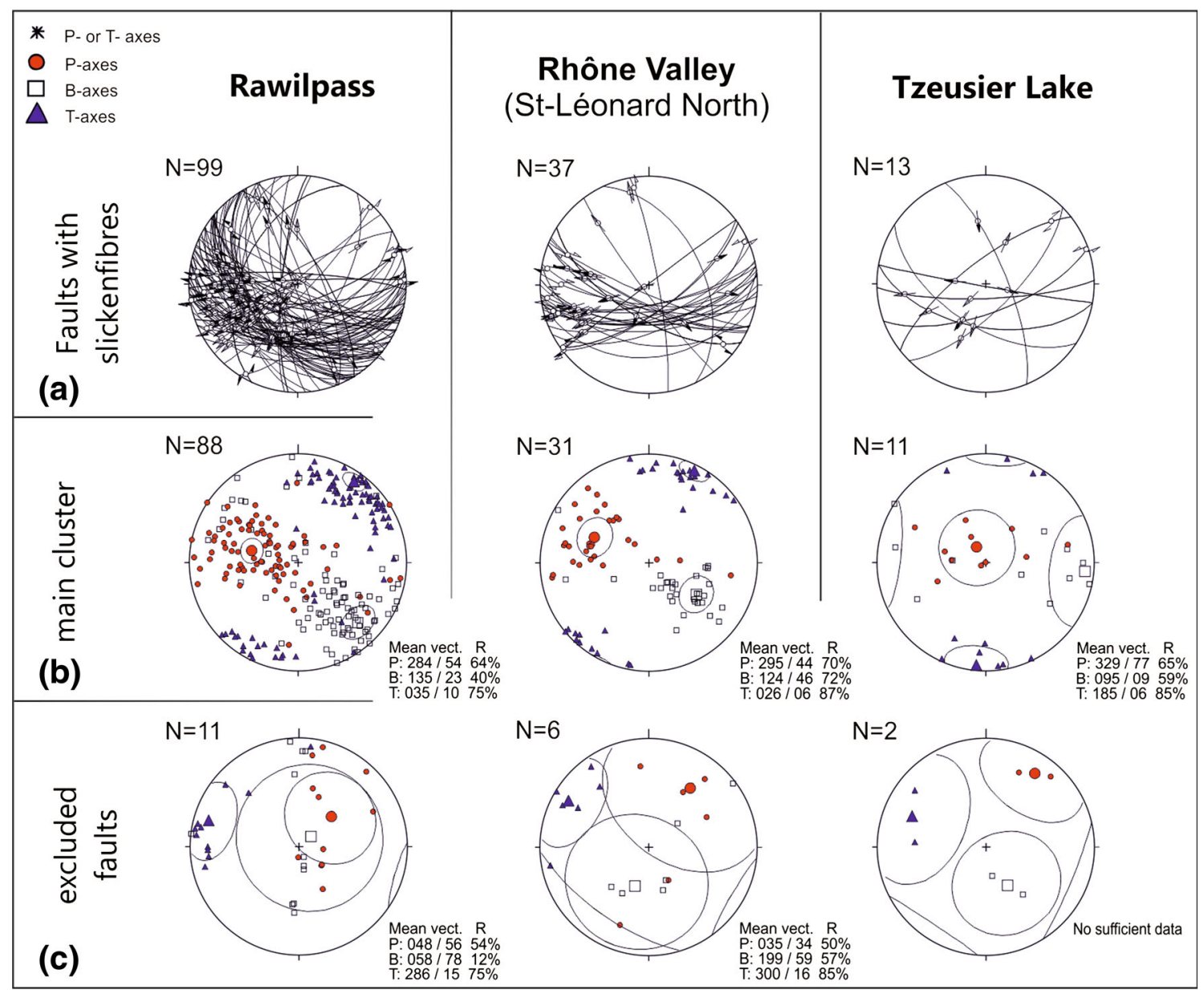

Fig. 11 Details for the most representative areas in the data set. Row a, great circle plots of faults with slickensides. Row b, main cluster of PBT axes. Row c, minor clusters from the faults excluded from the main cluster, roughly indicating extension to the WSW

Table 1 Orientation of the PBT-axes (plunge direction and angle) calculated according to Sperner et al. (1993) with the program Tectonics FP (Ortner et al. 2002)

\begin{tabular}{|c|c|c|c|c|c|c|c|c|c|c|}
\hline \multirow[t]{2}{*}{ Locality } & \multirow[t]{2}{*}{$\mathrm{N}$} & \multicolumn{2}{|l|}{$\mathrm{P}$} & \multirow[t]{2}{*}{$\mathrm{R}$} & \multicolumn{2}{|l|}{ B } & \multirow[t]{2}{*}{$\mathrm{R}$} & \multicolumn{2}{|l|}{$\mathrm{T}$} & \multirow[t]{2}{*}{$\mathrm{R}$} \\
\hline & & Dir. & Ang. & & Dir. & Ang. & & Dir. & Ang. & \\
\hline Gemmi-Rote Chumme region & 21 & 141 & 23 & 42 & 327 & 56 & 41 & 43 & 1 & 84 \\
\hline Wildstrubel north & 17 & 1 & 56 & 28 & 161 & 49 & 57 & 358 & 21 & 22 \\
\hline Rhône Valley (St-Léonard North) & 37 & 310 & 53 & 40 & 133 & 58 & 66 & 19 & 8 & 67 \\
\hline Rawilpass & 99 & 292 & 63 & 53 & 136 & 18 & 28 & 43 & 9 & 63 \\
\hline Tzeusier Lake & 13 & 359 & 71 & 55 & 96 & 7 & 40 & 177 & 1 & 65 \\
\hline Wildhorn SW & 15 & 274 & 55 & 64 & 154 & 47 & 33 & 44 & 22 & 61 \\
\hline Sublage & 3 & 172 & 31 & 94 & 302 & 48 & 94 & 66 & 27 & 96 \\
\hline Rhône Valley (Sion-Mont d'Orge) & 25 & 269 & 50 & 48 & 117 & 30 & 46 & 17 & 9 & 89 \\
\hline Sanetsch North & 5 & 89 & 32 & 38 & 233 & 70 & 83 & 97 & 5 & 21 \\
\hline Col du Sanetsch & 4 & 267 & 64 & 94 & 161 & 13 & 85 & 66 & 27 & 81 \\
\hline
\end{tabular}


Table 2 PBT-axes orientation (plunge direction and angle) of the main cluster

\begin{tabular}{|c|c|c|c|c|c|c|c|c|c|c|}
\hline \multirow[t]{2}{*}{ Locality } & \multirow[t]{2}{*}{$\mathrm{N}$} & \multicolumn{2}{|l|}{$\mathrm{P}$} & \multirow[t]{2}{*}{$\mathrm{R}$} & \multicolumn{2}{|l|}{ B } & \multirow[t]{2}{*}{$\mathrm{R}$} & \multicolumn{2}{|l|}{$\mathrm{T}$} & \multirow[t]{2}{*}{$\mathrm{R}$} \\
\hline & & Dir. & Ang. & & Dir. & Ang. & & Dir. & Ang. & \\
\hline Rawilpass & 88 & 284 & 54 & 64 & 135 & 23 & 40 & 35 & 10 & 75 \\
\hline Rhône Valley (St-Léonard North) & 31 & 295 & 70 & 44 & 124 & 46 & 72 & 26 & 6 & 87 \\
\hline Tzeusier Lake & 11 & 329 & 77 & 65 & 95 & 9 & 59 & 185 & 6 & 85 \\
\hline
\end{tabular}

\begin{tabular}{|c|c|c|c|c|c|c|c|c|c|c|}
\hline \multirow[t]{2}{*}{ Locality } & \multirow[t]{2}{*}{$\mathrm{N}$} & \multicolumn{2}{|l|}{$\mathrm{P}$} & \multirow[t]{2}{*}{$\mathrm{R}$} & \multicolumn{2}{|l|}{ B } & \multirow[t]{2}{*}{$\mathrm{R}$} & \multicolumn{2}{|l|}{$\mathrm{T}$} & $\mathrm{R}$ \\
\hline & & Dir. & Ang. & & Dir. & Ang. & & Dir. & Ang. & \\
\hline Rawilpass & 11 & 48 & 56 & 54 & 50 & 78 & 12 & 286 & 15 & 75 \\
\hline Rhône Valley (St-Léonard North) & 6 & 35 & 34 & 50 & 199 & 59 & 57 & 300 & 16 & 85 \\
\hline
\end{tabular}

Table 3 PBT-axes orientation (plunge direction and angle) of the secondary cluster
Heim 1920; Günzler-Seiffert 1941), which initiated under very low greenschist metamorphic grade in the south and progressively colder and shallower PT conditions in the 'frontal region'. During doming of the external massifs in the Neogene, the older thrusts have been further tilted and now dip toward the north in the northern part, whereas close to the Rhône Valley they have been steepened and dip to the south. The wavelength of this regional antiform is on the order of $10 \mathrm{~km}$, indicating crustal-scale folding during the latest stages of collision. A possible interpretation of the irregularly developed and relatively minor $\mathrm{D}_{3-4}$ folds is that they could result from dome-and-basin fold interference during exhumation and offset of the Mont Blanc/Aiguilles Rouges and Aar/Gastern External Crystalline Massifs, related to development of the Rawil Depression (e.g. Reinecker et al. 2008; Glotzbach et al. 2011, Cardello et al. 2015).

\subsection{Stretching during crustal extension}

During the Neogene, the whole Rawil region was cross-cut by low- to high-angle faults with generally oblique dextral transtensive displacement, which are closely associated with more diffuse veining and pressure-solution (i.e. stylolites). Fault development is related to differential exhumation of the External Crystalline Massifs since 17-15 Ma (Cardello et al. 2015), coeval with activity along the Simplon-Rhône Fault. On a regional scale, the Rawil Depression forms the northern footwall of the SimplonRhône Fault. Most of the late Alpine faults cropping out in the study area (Figs. 1, 12) already initiated in the Early to Middle Miocene but, as suggested already by Ustaszewski and Pfiffner (2008), some may have also been recently active. Accumulated displacements range up to ca. $0.7-1.25 \mathrm{~km}$ on the major structures, such as the Rezli Fault (Burkhard 1988; Gasser and Mancktelow 2010), the Iffigensee Fault (Burkhard 1988; Huggenberger and Aebli 1989), and the Mondraleche Fault (Lugeon 1914-1918),

After burial and thrusting, the Helvetic nappe structure has been progressively folded into a broad antiform (e.g. 


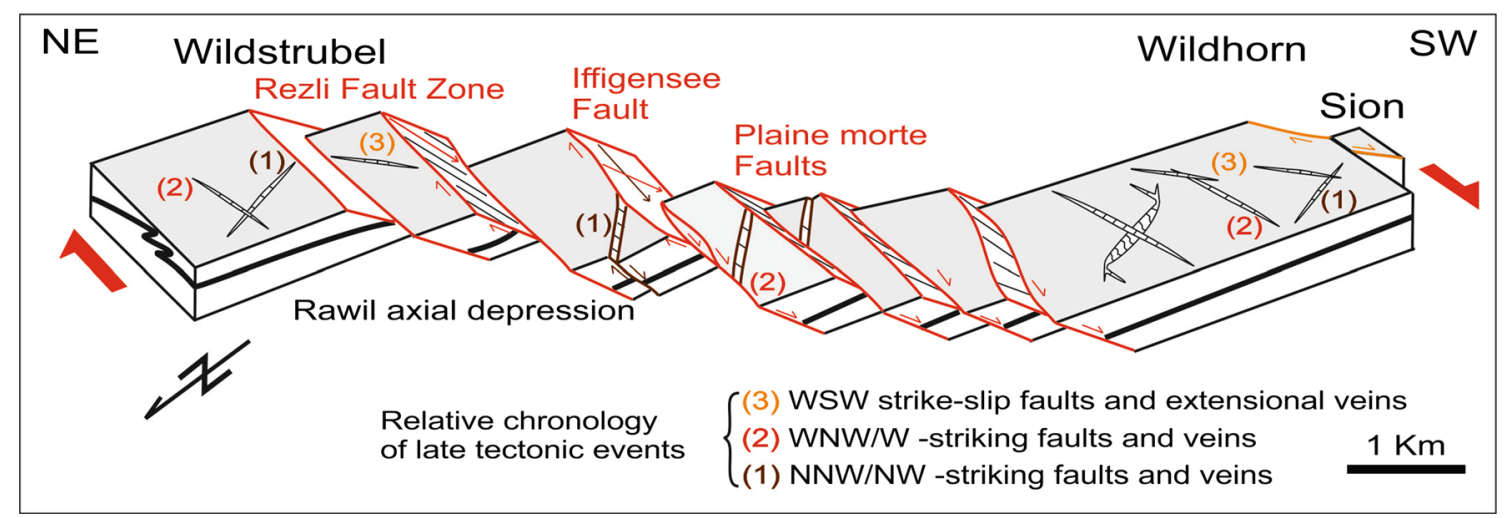

Fig. 12 Schematic model for the evolution of faulting and veining in the Rawil Depression

but they are more typically on the order of a few tens of metres across much shorter and less continuous minor faults. The major faults in the Rawil area are spaced around $1 \mathrm{~km}$ apart and show similar features (Fig. 1), whereas small-scale faulting is much more diffuse. Burkhard (1988) noted that this orogen-parallel extension related to faulting was augmented by a weak, more distributed ductile component, estimated to be around $20-30 \%$, as indicated by fibrous haloes developed on pyrites recording the same stretching direction.

As evident from clumped-isotope temperatures on calcite (Cardello 2013), the high- to moderate-angle obliquenormal faults cross-cutting the Helvetic nappes initiated at temperatures of ca $180-190{ }^{\circ} \mathrm{C}$, corresponding to conditions appropriate for the brittle-ductile transition in carbonates. They were active for more than 10 million years, from ca. 17 to about 5 Ma. Faulting in the Simplon region, associated with doming and orogen-parallel extension in the internal axial zone of the Alps, also occurred since ca. 18.5 Ma (Campani et al. 2014) and is therefore effectively coeval with faulting in the Rawil Depression. In the Rawil Depression, the evolution of fault systems from partially ductile to brittle conditions during exhumation is well preserved (Gasser and Mancktelow 2010), allowing the study of the fault displacement at depths near the base of the seismogenic zone, where most major earthquakes initiate. Fault plane solutions for earthquakes developed at depths $<10 \mathrm{~km}$ in the region north of the Rhône Valley are also consistent with the WNW-ESE trend and transtensional kinematics of exhumed faults in the Rawil Depression (Pavoni 1980; Maurer et al. 1997; Kastrup et al. 2004; Diehl et al. 2013). The interpreted depth to top basement of the External Crystalline Massifs in the Rawil Depression is controversial. Burkhard (1988, his Fig. 10a) and Pfiffner et al. (1997, their Fig. 13.1-25) predict that it should occur at depths around $4 \mathrm{~km}$, whereas Steck et al. (1997, their Fig. 12-15) predict significantly greater values on the order of 7-10 km. In all these models, there is a rapid deepening to values greater than $10 \mathrm{~km}$ toward the Rhône Valley, reflecting the structural steepening in this direction. The depth of earthquake focal mechanisms in the same area shows a spread from near surface down to about $10 \mathrm{~km}$, where there is a distinct decrease in number, with very few at depths greater than $15 \mathrm{~km}$ (http://www.seismo.ethz.ch; Maurer et al. 1977). Many, if not most, of the common earthquakes north of the Rhône Valley should therefore occur in carbonate-rich Helvetic sedimentary units, similar to those studied here.

All these transtensional faults are inferred to post-date nappe-related folding, because faults of sets (1) and (2) obliquely cross-cut the fold system and the fold geometry can be quite well-matched on either side. As noted above, some of these faults also cross-cut and offset nappe boundaries (e.g. the boundary between the Doldenhorn and Gellihorn nappes in the Gemmi area). Normal to oblique faulting during the Neogene developed during exhumation related to WSW-extension, parallel or slightly oblique to the main trend of Alpine fold axes. However further to the NE within the Helvetic nappe stack, in the Säntis area, similar cross-faults are interpreted to be coeval with nappe folding (Pfiffner et al. 2011; Sala et al. 2014), because of the distinctly different fold geometry to either side of the fault planes.

Fault sets (1) and (2) appear to be broadly coeval, as indicated in the Rawil-Plaine Morte area by many examples of branching and bending of one set into the other and by similar displacement directions and deformation fabrics. Nevertheless, there are clear examples (e.g. along the Wildstrubelhütte segment of the Iffigensee Fault, Fig. 8) of set (2) crosscutting set (1), which establishes, at least locally, a chronological succession of faulting events. Calcite slickenlines and fibres on fault planes (1) and (2) indicate two main slip directions. The older is WSW-directed and generally plunges around $25^{\circ}$, whereas the younger one plunges toward $\mathrm{S}$, with a steeper, mainly dip-slip related movement (Fig. 8d). In general, fault set (3) seems to be 
more brittle, although the local observation of ductile precursors related to right lateral shear may indicate that this set has also been active in the ductile (and older) regime. In accord with the findings of Delacou et al. (2004) regarding late deformation in the Alps, the general transition from strike-slip to more dip-slip faulting may reflect the increasing influence of gravitational collapse as convergence rates across the orogen decreased, with a consequent transition to extension more perpendicular to the chain. However, as shown in the numerical experiments of Pfiffner et al. (2000), such orogen-perpendicular extension can also occur without a decrease in convergence rates, due to extensional collapse of the rising plug in the core of the orogen.

Transtensive post-nappe disruption may contribute to the final stages of formation of doming related to the Rawil depression, with the result that the location where the highest nappes are preserved is shifted ca. $5 \mathrm{~km}$ to the $\mathrm{SW}$ (i.e. in the area of the Rawilpass) with respect to the axial depression, where the fold axes are horizontal (Wildstrubel area). This suggests the more brittle faults dissected the former structure during its late formation, down-dropping it to the south.

Fault sets (1) and (2) of the alpine axial region have an overall regional en-échelon distribution along an E-W strike, which kinematically would correspond to a dextral wrench-zone (Fig. 12). This wrench zone affects a wide area from the Gemmipass region, where faults have little displacement, to a few kilometres west of the Wildhorn. Most of the transtensional deformation is accumulated in this area. Such a broad wrench zone would be in accord with the proposal of Burkhard (1988) that $\mathrm{D}_{3-4}$ compression (his "Grindelwald phase") could be due to a transpressional ramp in the frontal thrust zone (e.g. Kastrup et al. 2004), where Mont Blanc and Aar Massif thrust directions differ by about $20^{\circ}$ around the Alpine arc, causing transtension in the area of the Rawil Depression (cf. Pfiffner et al. 2009, Egli and Mancktelow 2013, Cardello et al. 2015). On the other hand, dextral transcurrent kinematics are also a typical characteristic of the Alps related to the CCW rotation of Adria during collision with Europe (e.g. Steck 1984; Mancktelow 1992; Schmid et al. 1989; Pleuger et al. 2012).

At the southern edge of this E-W wrench-zone, as defined by the termination tips of the main faults of sets (1) and (2), the fault set (3) develops another dextral wrench zone parallel to the Rhône Valley. This is bounded by the Mondraleche and La Brune Faults to the north and the main segment of the Simplon-Rhône Fault, buried under the Rhône Valley, to the south. Fault set (3) is associated with the Simplon-Rhône Fault zone (Burkhard 1988; Hubbard and Mancktelow 1992; Reinecker et al. 2008; Gasser and Mancktelow 2010), probably active throughout much of the Neogene and possibly also into the Quaternary.
Extension perpendicular to the fold axes may be related to extension in the axial region but also to broader scale effects related to the Simplon-Rhône Fault which, according to Reinecker et al. (2008), should have also been active during the last 3.5 Ma. This interpretation is further supported by palaeomagnetic data (Cardello et al. 2015), which consistently show a tilt toward the foreland of the Aar Massif as a result of the top-down-to-the-south normal component on the Simplon-Rhône Fault. This phase can be directly related to both fault set (3) and vein set (3). Burkhard (1988) called this transtensional event the 'SimplonRhône phase'.

\subsection{Kinematics of oblique-normal faulting}

Different fault solutions obtained from focal mechanisms of earthquakes $\left(M_{w}<5\right)$ occurring in SW Switzerland suggest that different active fault sets may coexist within the same region (Kastrup et al. 2004). Areas with homogeneous behaviour can be distinguished both in crosssection and on the map (e.g. strike-slip faulting in the foreland domain, thrusting at depth in the frontal region, oblique-normal faulting in the hinge of the dome and on its back-limb, normal faulting in the Penninic units; Pavoni 1980; Maurer et al. 1997; Burkhard and Sommaruga 1998; Kastrup et al. 2004).

Alternatively, as observed in the SW Helvetics, the change from more strike-slip to more dip-slip kinematics and vice versa, as recorded by kinematic indicators (e.g. slickenfibres) on the oblique-normal faults in this study, seems to depend on the change in orientation and magnitude of the principal axes of stress. Considering that veining is strongly associated with faulting, especially during fault initiation, a comparison can be made between the palaeostress results (PBT axes) obtained by inversion techniques applied to faults and the progressive incremental strain history recorded in veins. If the $\mathrm{T}$-axes are parallel to the direction of both the $e_{3}$ and $\sigma_{3}$ axes for an infinitesimally short time period of deformation (i.e. assuming effectively isotropic material behaviour), stretching on veins and faults should record the same strain increment (and related stress field) at the same time. Incremental strain in veins is recorded by the initial growth opening direction perpendicular to the vein walls and subsequently by the direction of internal fibres, which record progressive changes in the stretching direction. From this comparison, it can be inferred that initiation of the oblique-normal faults occurred in a stress regime showing strong variation in the position of the $\mathrm{P}$ - and $\mathrm{B}$-axes within a girdle perpendicular to a well-defined and constant T-axis. This is already observed even within the fault precursor, which can be identified as the brittle-ductile en-échelon shear zones. P- and B-axes may either flip 
or lie on a great circle around the T-axes, which consistently plunge gently to the SW, suggesting overall uniaxial extension (Fig. 5b). As reported in Cardello et al. (2015), AMS fabrics measured from rock samples collected in the same area show a similar pattern to the PBT "stress inversion" analysis of faults. The main susceptibility axis $\left(\mathrm{k}_{1}\right)$ is parallel to the T-axis, with a shallow mean plunge toward the SW. In most sites, the intermediate $\left(\mathrm{k}_{2}\right)$ and minimum $\left(\mathrm{k}_{3}\right)$ axes either form a great circle girdle or flip their position, as also observed for the P- and B-axes determined from fault analysis.

Despite the progressive, generally counter-clockwise rotation of the stretching direction toward the SE documented by the crosscutting relationships of veins far from faults, an overall dominant phase of stretching toward the $\mathrm{SW}$ is observed. The Gemmipass region, where movements are considered active into the Quaternary (Ustaszewski et al. 2007), still shows the same tendency, with a constant $\mathrm{S}(\mathrm{SW}) \mathrm{T}$-axis and P- and B-axes that flip or form a girdle. The resultant PBT diagrams are directly comparable with the stress field calculated from the present-day seismic focal mechanisms for the same area (Kastrup et al. 2004), which also have sub-horizontal $\mathrm{T}$ (or $\sigma_{3}$ ) axes plunging $\mathrm{SW}$. This suggests that most of the outcropping faults in the Rawil depression could readily be reactivated in the present stress field. Nevertheless, apart from the Gemmipass region, where Quaternary activity was recognized (Ustaszewski et al. 2007), little evidence for recent overprint on the Neogene exhumed faults could be found.

\subsection{Initiation and development of oblique-normal faulting}

In the Rawil depression the evolution of fault systems from partially ductile to brittle conditions is well preserved during exhumation (Fig. 12), providing information regarding initiation and development of oblique-normal faults. Throughout the area, this transtensive displacement is closely associated with diffuse veining and pressuresolution (i.e. stylolites).

Low- to high-angle faults, both of which are represented in fault sets (1) and (2), show the same kinematics for both ductile and brittle structures, establishing that these faults were exhumed through the brittle-ductile transition in a constant tectonic regime. Furthermore, clear crosscutting relationships demonstrate that once a fault had terminated its activity it could not be easily reactivated, but was instead cross-cut by a newly formed fault. The fault structure is closely related to the opening of veins (1) and (2), indicating that the more regional stretching that opened these veins is the same as that causing first the brittleductile shear zones and then the brittle faults. Fault sets (1) and (2) recorded this brittle overprint but do not show any clear evidence for recent activity with geomorphic expression. However, the isotopic values, as reported in Cardello (2013), indicate that these structures may have continued to have been active to a depth of $<3 \mathrm{~km}$. Locally, there is a transition from an initial dominantly ductile mylonitic fabric to a cataclasitic one, which shows that these fault rocks were exhumed from a depth of about $7 \mathrm{~km}$ and were active until a depth of ca. $4 \mathrm{~km}$. The final displacement is the cumulative value derived from the sum of the ductile and brittle deformational components.

Fault initiation seems to start during an advanced stage of brittle-ductile shear, suggesting shear localization during progressive intracrystalline deformation and recrystallization of the already precipitated calcite in the fault zone and in the en-échelon veins. The product of this process of progressive shear and re-crystallization on a brittle precursor is finally a highly deformed and strongly foliated rock having the texture of a mylonite (e.g. Fig. 3c). At the microscopic scale, veins are stretched and rotated parallel to the foliation, with their internal grain size reduced by dynamic recrystallization. Relict clasts are rotated during progressive shear to high strain. In the case of the Rezli Fault, this has locally produced delta-clast geometries (Cardello and Tesei 2013). Pressure-solution is mainly concentrated on levels reworked by later brittle-ductile to cataclastic faulting, as evident along the more localized slip surfaces bounding and crosscutting the mylonitic zones (Fig. 7). The thickness of mylonitic zones preserved in the fault cores of faults with different lengths and cumulative displacements is similar, indicating that it is rather scale independent. As evident from the example of the Tsa Bonna Fault, mylonites are typically related to an initial shear zone with a width up to $2 \mathrm{~m}$ and an offset not larger than $50 \mathrm{~m}$. Although often reworked during cataclastic flow, the thickness of the mylonitic zone and its structure is still quite well preserved in the Wildhorn Fault (Fig. 7c-d), and in the Iffigensee and Rezli Fault Zones, where it is maintained within tectonic lenses up to $0.5-1.5 \mathrm{~m}$ thick bounded by principal slip surfaces (Figs. 7a, 8c). Later displacement is concentrated on a few discrete slip surfaces that accommodate most of the total displacement. Many precursor mylonitic shear zones were probably completely obliterated by later brittle fault fabrics. Mylonites crossed by pressure-solution seams may possibly represent an intermediate stage between more distributed continuous shear and recrystallization and later localized embrittlement (Fig. 7d).

In this interpretation, brittle-ductile behaviour may show a progressive transition to a more brittle faulting rather than a discrete and sudden change. During subsequent brittle faulting closer to the surface, cataclasites are clearly related to polycyclic subsequent accumulation of slip. Different generations of slickenfibres and re-brecciation reflect the 
evolution of these faults through time. In a later stage associated with rapid uplift, some faults are reactivated as purely brittle structures, characterized by matrix production at lower temperatures and circulation of meteoric fluids within the fault core (Cardello 2013; Cardello and Tesei 2013). Since faults of sets (1) and (2) developed across the ductile-brittle transition in limestones, shales and marls (e.g. Fig 7e), they may represent fossil seismogenic zones in rocks with high pore-fluid pressure, corresponding to earthquakes developed in carbonate rocks at depths of around 7-9 km. Current seismicity at this depth north of the Rhône Valley (e.g. Maurer et al. 1997) could also occur, at least in part, within carbonate rocks, although the depth to top-basement in this region is not well established (Burkhard 1988; Pfiffner et al. 1997; Steck et al. 1997). At similar depths in the Apennines (Chiarabba et al. 2009), major earthquakes also occur in carbonates, so the exposed fossil fault structures studied here can provide important constraints both on the older history in the Rawil Depression and the current situation in other regions as well. The faults in the Gemmi pass region cross-cut nappe boundaries and kinematically are in accord with NW-compression and SW-directed extension, again with a tendency for interchange of the P- and B-axes. On the other hand, they clearly show a fault fabric characterized by intense cataclasis and up to $1.5 \mathrm{~m}$ thick zones of newly crystallized euhedral calcite, which according to Ustaszewski and Pfiffner (2008) is typical of more brittle and recent faults. There is thus evidence for seismicity during continued activity of these faults as they were exhumed. This provides a model for the current seismicity at depths $<5 \mathrm{~km}$ north of the Rhône Valley, which has similar kinematics and is interpreted to develop in comparable carbonate-rich sediments.

\section{Conclusion}

This field study provides a synopsis of the transition, in this sector of the Alps, from initial thrusting and burial to increasingly brittle faulting during exhumation. The later Neogene faults and veins define the latest evolutionary steps from ductile to brittle behaviour and from nappe stacking to doming and transtensive post-nappe disruption during exhumation. Progressive ductile to brittle fault localization is observed at the local and regional scale. During this period, the principal direction of extension rotated, in a generally counter-clockwise sense, reflecting a change from NW-directed shear during stacking to more SW-directed extension parallel to the fold axes and, finally, a late minor SE-directed extension perpendicular to the orogen trend. A change from more distributed to more localized faulting has also been observed associated with the transition from ductile shear to progressively more brittle faulting. En-échelon vein arrays are concentrated along faults, with both the vein array and the fault showing the same shear kinematics. After progressive ductile-brittle shear, recrystallization and ductile shear overprints some brittle precursors within brittle-ductile shear zones. Mylonites are subsequently cross-cut by more localized slip surfaces, which accumulate most of the fault offset. Oblique-normal faults are not explained by the simple dynamic models of Anderson (1951) but develop with a generally fixed T-axis position plunging shallowly toward the SW, associated with less well defined $\mathrm{P}$ - and $\mathrm{B}$-axes that interchange their positions or form a girdle perpendicular to T-axes. This interchange or spread along a girdle of the $\mathrm{P}$ and $\mathrm{B}$ axes occurs throughout the deformational history, indicating that the horizontal load due to convergence and the vertical gravitational load were generally of similar magnitude. The orientation and distribution of PBT axes determined from these exhumed fossil faults are identical to those of the principal stress axes derived from earthquake fault plane solutions in the same general area. Since faults of sets (1) and (2) developed across the brittle-ductile transition in limestones, shales and marls, they may represent fossil seismogenic zones in rocks with high porefluid pressure, representing exposed examples of seismic faults in similar rocks currently active at depths of ca. $7-9 \mathrm{~km}$.

Acknowledgments We thank the Swiss National Science Foundation (project number 2-77178-11) for financial support. Thanks also to Giulio Viola for discussions in the first stage of preparation of this manuscript and to Jara Schnyder, Andrea Mancini, Angelika Rosa, Eva Matzenauer and Rolf Bruijn for support and discussions in the field. Laurent Jolivet is thanked for his support during final manuscript preparation. Henry Masson, Adrian Pfiffner and Stefan Schmid are kindly thanked for their insightful and constructive comments.

\section{References}

Anderson, E. M. (1951). The dynamics of faulting (Oliver and Boyd, Edinburgh), 2nd ed.

Argand, E. (1916). Sur l'arc des Alpes Occidentales. Eclogae Geologicae Helvetiae, 14, 145-191.

Badoux H., Bonnard E.G., Burri M., Vischer A. (1959). Feuille 35 StLeonard et notice explicative. Atlas geol. Suisse 1:25'000. Comm. Geol. Suisse. Basel. Badoux H., Lombard A. (1962). Feuille 41 Lenk et notice explicative. Atlas geol. Suisse 1:25,000. Comm. Geol. Suisse. Bern.

Badoux, H., \& Lombard, A. (1962). Feuille 41 Lenk et notice explicative. Atlas geologique Suisse 1:25,000. Bern: Commission Geologique Suisse.

Bertrand, M. (1884). Rapport de structure des Alpes de Glarus et du bassin houiller du Nord. Societé Gèologique de France, 12(3), $318-330$

Bigi, G., \& Carrozzo, M. T. (1992). Structural model of Italy and gravity map 1:500,000. Consiglio Nazionale delle Ricerche. 
Bistacchi, A., Dal Piaz, G. V., Massironi, M., Zattin, M., \& Balestrieri, M. L. (2001). The Aosta-Ranzola extensional fault system and Oligocene-present evolution of the AustroalpinePenninic wedge in the northwestern Alps. International Journal of Earth Sciences, 90, 654-667.

Bistacchi, A., Eva, E., Massironi, M., \& Solarino, S. (2000). Miocene to present kinematics of the NW-Alps: evidences from remote sensing, structural analysis, seismotectonics and thermochronology. Journal of Geodynamics, 30, 205-228.

Bistacchi, A., \& Massironi, M. (1998). Neo-Alpine exhumation of the north-western Alps: a kinematic model from Oligocene to present. Memorie di Scienze Geologiche, 50, 93-94.

Bistacchi, A., \& Massironi, M. (1999). Oligocene to present extension across the north-western Alpine nappe stack. Journal of Conference Abstracts (EUG 10), 4, 32-33.

Bistacchi, A., \& Massironi, M. (2000). Post-nappe brittle tectonics and kinematic evolution of the north-western Alps: an integrated approach. Tectonophysics, 327, 267-292.

Burkhard, M. (1988). L'Helvétique de la bordure occidentale du massif de l'Aar (évolution tectonique et métamorfique). Eclogae Geologicae Helvetiae, 81, 63-114.

Burkhard, M. (1993). Calcite twins, their geometry, appearance and significance as stress-strain markers and indicators of tectonic regime: a review. Journal of Structural Geology, 15(3), 351-368.

Burkhard, M., \& Goy-Eggenberger, D. (2001). Near vertical iso-illitecrystallinity surfaces cross-cut the recumbent fold structure of the Morcles nappe, Swiss Alps. Clay Minerals, 36(2), 159-170.

Burkhard, M., \& Kerrich, R. (1988). Fluid regimes in the deformation of the Helvetic Nappes, Switzerland, as inferred from stable isotope data. Contributions to Mineralogy and Petrology, 99, 416-429.

Burkhard, M., \& Sommaruga, A. (1998). Evolution of the western Swiss Molasse basin: structural relations with the Alps and the Jura belt. Cenozoic foreland basins of Western Europe, 134, 279-298.

Burri, M. (1969). La zone de Sion-Courmayeur entre les Vallées de Bagnes et d'Entremont (Valais). Eclogae Geologicae Helvetiae, 62(2), 547

Bussy, F., \& Epard, J.-L. (1984). Essai de zonéographie métamorphique entre les Diablerets et le massif de l'Aar (Suisse occidentale), basée sur l'étude des Grès de Taveyanne. Schweizerische Mineralogische und Petrographische Mitteilungen, 64, 131-150.

Campani, M., Mancktelow, N., \& Courrioux, G. (2014). The 3D interplay between folding and faulting in a syn-orogenic extensional system: the Simplon Fault Zone in the Central Alps (Switzerland and Italy). Swiss Journal of Geosciences, 107(2-3), 251-271.

Cardello, G.L. (2013). The Rawil depression: its structural history from Cretaceous to Neogene. Ph.D. dissertation, Switzerland. ETH Zurich. doi:10.3929/ethz-a-010016215.

Cardello, G. L., Almqvist, S. B., Hirt, A. M., \& Mancktelow, N. S. (2015). Determining the timing of formation of the Rawil Depression in the Helvetic Alps with the use of paleomagnetic and structural methods. Geological Society, London, Special Publication,. doi:10.1144/SP425.4.

Cardello, G. L., \& Doglioni, C. (2015). From Mesozoic rifting to Apennine orogeny: the Gran Sasso range (Italy). Gondwana Research, 27(4), 1307-1334.

Cardello, G. L., \& Mancktelow, N. S. (2014). Cretaceous synsedimentary faulting in the Wildhorn Nappe (SW Switzerland). Swiss Journal of Geosciences, 107(2-3), 223-250.

Cardello, G. L., \& Tesei, T. (2013). Transtensive faulting in carbonates at different crustal levels: examples from SW
Helvetics and Central Apennines. Rendiconti online della Società Geologica Italiana, 29, 20-23.

Casey, M., Dietrich, D., \& Ramsay, J. G. (1983). Methods for determining deformation history for chocolate tablet boudinage with fibrous crystals. Tectonophysics, 92(1), 211-239.

Champagnac, J.-D., Sue, C., Delacou, B., \& Burkhard, M. (2003). Brittle orogen-parallel extension in the internal zones of the Swiss Alps (South Valais). Eclogae Geologicae Helvetiae, 96, 325-338.

Champagnac, J.-D., Sue, C., Delacou, B., \& Burkhard, M. (2004). Brittle deformation in the inner NW Alps: from early orogenparallel extrusion to late orogen-perpendicular collapse. Terra Nova, 16, 232-242.

Chiarabba, C., Amato, A., Anselmi, M., Baccheschi, P., Bianchi, I., Cattaneo, M., Cecere, G., Chiaraluce, L., Ciaccio, M. G., De Gori, P., De Luca, G., Di Bona, M., Di Stefano, R., Faenza, L., Govoni, A., Improta, L., Lucente, F. P., Marchetti, A., Margheriti, L., Mele, F., Michelini, A., Monachesi, G., Moretti, M., Pastori, M., Piana Agostinetti, N., Piccinini, D., Roselli, P., Seccia, D., \& Valoroso, L. (2009). The 2009 L'Aquila (central Italy) Mw 6.3 earthquake: Main shock and aftershocks. Geophysical Research Letters, 36, L18308, doi:10.1029/ 2009 GL039627.

Chiaraluce, L. (2012). Unravelling the complexity of Apenninic extensional fault systems: a review of the 2009 L'Aquila earthquake (Central Apennines, Italy). Journal of Structural Geology, 42, 2-18.

Clark, S. P., \& Niblett, E. R. (1956). Terrestrial heat flow in the Swiss Alps. Geophysical Journal International, 7(4), 176-195.

Crespo-Blanc, A., Masson, H., Sharp, Z., Cosca, M., \& Hunziker, J. (1995). A stable and 40Ar/39Ar isotope study of a major thrust in the Helvetic nappes (Swiss Alps): Evidence for fluid flow and constraints on nappe kinematics. Geological Society of America Bulletin, October 1995, 107(10); 1129-1144.

Delacou, B., Sue, C., Champagnac, J. D., \& Burkhard, M. (2004). Present-day geodynamics in the bend of the western and central Alps as constrained by earthquake analysis. Geophysical Journal International, 158, 753-774.

Diehl, T., Deichmann, N., Clinton, J., Husen, S., Kraft, T., Plenkers, K., et al. (2013). Earthquakes in Switzerland and surrounding regions during 2012. Swiss Journal of Geosciences, 106(3), 543-558.

Dietrich, D. (1989). Fold-axis parallel extension in an arcuate foldand thrust belt: the case of the Helvetic nappes. Tectonophysics, 170(3), 183-212.

Dietrich, D., \& Durney, D. W. (1986). Change of direction of overthrust shear in the Helvetic nappes of western Switzerland. Journal of Structural Geology, 8, 389-398.

Dietrich, D., McKenzie, J. A., \& Song, H. (1983). Origin of calcite in syntectonic veins as determined from carbon-isotope ratios. Geology, 11, 547-551.

Durney, D. W., \& Ramsay, J. G. (1973). Incremental strains measured by syntectonic crystal growths. Gravity and tectonics, 67, 96.

Escher, A., Masson, H., \& Steck, A. (1993). Nappe geometry in the Western Swiss Alps. Journal of Structural Geology, 15, 501-509.

Franck, P., Wagner, J. J., Escher, A., \& Pavoni, N. (1984). Evolution des contraintes tectoniques et sismicité dans la région du col du Sanetsch. Alpes valaisannes hélvetiques. Eclogae Geologicae Helvetiae, 77(2), 383-393.

Frischknecht, C., Rosset, P., \& Wagner, J. J. (2005). Toward seismic microzonation-2-D modeling and ambient seismic noise measurements: the case of an embanked, deep alpine valley. Earthquake Spectra, 21(3), 635-651.

Gasser, D., \& Mancktelow, N. S. (2010). Brittle faulting in the Rawil depression: field observations from the Rezli fault zones, 
Helvetic nappes, Western Switzerland. Swiss Journal of Geosciences, 103, 15-32.

Glotzbach, C., Van Der Beek, P. A., \& Spiegel, C. (2011). Episodic exhumation and relief growth in the Mont Blanc massif, Western Alps from numerical modelling of thermochronology data. Earth and Planetary Science Letters, 304(3), 417-430.

Grosjean, G., Sue, C., \& Burkhard, M. (2004). Late Neogene extension in the vicinity of the Simplon fault zone (central Alps, Switzerland). Eclogae Geologicae Helvetiae, 97, 33-46.

Gubler, E., Kahle, H. G., Klingele, E., Müller, S., \& Olivier, R. (1981). Recent crustal movements in Switzerland and their geophysical interpretation. Tectonophysics, 38, 297-315.

Günzler-Seiffert, H. (1941). Persistente Brücke im Jura der WildhornDecke des Berner Oberlandes. Eclogae Geologicae Helvetiae, 34(2), 164-172.

Günzler-Seiffert, H. (1952). Alte Brücke im Kreide/Tertiär-Anteil der Wildhorndecke zwischen Rhone und Rhein. Geologisches Rundshau, 40(2), 211.

Hänni, R. \& Pfiffner, O. A. (2001). Evolution and internal structure of the Helvetic nappes in the Bernese Oberland. Eclogae Geologicae Helvetiae, 94, 161-171.

Heim, A. (1920). Geologie der Schweiz. B. Tauchnitz Verlag Gmbh, Leipzig.Kastrup, U., Zoback, M.L., Deichmann, N., Evans, K.F., Giardini, D., \& Michael, A.J. (2004). Stress field variations in the Swiss Alps and the northern Alpine foreland derived from inversion of fault plane solutions. Journal of Geophysical Research, 109, B01402, doi:10.1029/2003JB002550.

Herb, R. (1988). Eocaene Palaeogeographie und Palaeotektonik des Helvetikums. Eclogae Geologicae Helvetiae, 81, 611-657.

Hoffmann, B. A., Helfer, M., Diamond, L. W., Villa, I. M., Frei, R., \& Eikenberg, J. (2004). Topography-driven hydrothermal breccia mineralization of Pliocene age at Grimsel Pass, Aar massif, Central Swiss Alps. Schweizerische Mineralogische und Petrographische Mitteilungen, 84, 271-302.

Hubbard, M., \& Mancktelow, N. S. (1992). Lateral displacement during Neogene convergence in the western and central Alps. Geology, 20(10), 943-946.

Huggenberger, P., \& Aebli, H. (1989). Bruchtektonik und Blattverschiebungen im Gebiet des Rawil-Passes; Resultat einer E-W gerichteten dextralen Schwerbewegung im kristallinen Untergrund? Schweizerische Mineralogische und Petrographische Mitteilungen, 69, 173-180.

Jeanbourquin, P. (1994). Early deformation of Ultrahelvetique mélanges in the Helvetic nappes (Western Swiss Alps). Journal of Structural Geology, 16(10), 1367-1383.

Kastrup, U., Zoback, M. L., Deichmann, N., Evans, K. F., Giardini, D., \& Michael, A. J. (2004). Stress field variations in the Swiss Alps and the northern Alpine foreland derived from inversion of fault plane solutions. Journal of Geophysical Research, 109, B01402. doi:10.1029/2003JB002550.

Kempf, O., \& Pfiffner, O. A. (2004). Early Tertiary evolution of the North Alpine Foreland Basin of the Swiss Alps and adjoining areas. Basin Research, 16(4), 549-567.

Kirschner, D. L., Masson, H., \& Cosca, M. A. (2003). An ${ }^{40} \mathrm{Ar} /{ }^{39} \mathrm{Ar}$, $\mathrm{Rb} / \mathrm{Sr}$, and stable isotope study of micas in low-grade fold-andthrust belt: an example from the Swiss Helvetic Alps. Contributions to Mineralogy and Petrology, 145, 460-480.

Lugeon, M. (1902). Les grandes nappes de recouvrement des Alpes du Chablais et de la Suisse. Bulletin de la Société Géologique de France, 4, 723-825.

Lugeon, M. (1914-1918). Les Hautes Alpes calcaires entre la Lizerne et la Kander : (Wildhorn, Wildstrubel, Balmhorn et Torrenthorn) : (explication de la carte spéciale no. 60). 3 Fascicule. Matériaux pour la carte géologique de la Suisse. Nouvelle série 60.

Mancktelow, N. S. (1992). Neogene lateral extension during convergence in the Central Alps: evidence from interrelated faulting and backfolding around the Simplonpass (Switzerland). Tectonophysics, 215(3), 295-317.

Masson, H., Baud, A., Escher, A., Gabus, J., \& Marthaler, M. (1980a). Compte rendu de l'excursion de la Société Géologique Suisse du 1 au 3 octobre 1979: coupe Préalpes-Helvétique-Pennique en Suisse occidentale. Eclogae Geologicae Helvetiae, 73, 331-349.

Masson, H., Herb, R., \& Steck, A. (1980b). Helvetic Alps of Western Switzerland, The Geology of Switzerland, A Guide Book. Part B (pp. 109-153). Basel: Birkhäuserverlag.

Maurer, H. R., Burkhard, M., Deichmann, N., \& Green, A. G. (1997). Active tectonism in the central Alps: contrasting stress regimes north and south of the Rhone Valley. Terra Nova, 9, 91-94.

Mazzoli, S., \& Di Bucci, D. (2003). Critical displacement for normal fault nucleation from en-échelon vein arrays in limestones: a case study from the southern Apennines (Italy). Journal of Structural Geology, 25(7), 1011-1020.

Mazzoli, S., Invernizzi, C., Marchegiani, L., Mattioni, L., \& Cello, G. (2004). Brittle-ductile shear zone evolution and fault initiation in limestones, Monte Cugnone (Lucania), southern Apennines, Italy. Geological Society, London, Special Publications, 224(1), 353-373.

Mohn, G., Manatschal, G., Müntener, O., Beltrando, M., \& Masini, E. (2010). Unravelling the interaction between tectonic and sedimentary processes during lithospheric thinning in the Alpine Tethys margins. International Journal of Earth Sciences, 99(Suppl. 1), 75-101.

Ortner, H., Reiter, F., \& Acs, P. (2002). Easy handling of tectonic data: the programs TectonicVB for Mac and TectonicsFP for Windows $^{\mathrm{TM}}$. Computers and Geosciences, 28(10), 1193-1200.

Pavoni, N. (1980). Comparison of focal mechanisms of earthquakes and faulting in the Helvetic zone of the Central Valais, Swiss Alps. Eclogae Geologicae Helvetiae, 73, 551-558.

Peacock, D. C. P., \& Sanderson, D. J. (1995). Strike-slip relay ramps. Journal of Structural Geology, 17(10), 1351-1360.

Pennacchioni, G., \& Mancktelow, N. S. (2013). Initiation and growth of strike-slip faults within intact metagranitoid (Neves area, eastern Alps, Italy). Geological Society of America Bulletin, 125(9-10), 1468-1483.

Pfiffner, O. A. (1993). The structure of the Helvetic nappes and its relation to the mechanical stratigraphy. Journal of Structural Geology, 15, 511-521.

Pfiffner, O. A. (2009). Geologie der Alpen. Bern/Stuttgart/Wien: Haupt Verlag.

Pfiffner, O.A. (2011). Structural Map of the Helvetic zone of the Swiss Alps including Voralberg (Austria) and Haute Savoie (France) 1:100'000. Federal Office of Topography SwissTopo.

Pfiffner, O. A., Ellis, S., \& Beaumont, C. (2000). Collision tectonics in the Swiss Alps: insight from geodynamic modeling. Tectonics, 19(6), 1065-1094.

Pfiffner, O.A., Sahli, S. \& Stäuble, M. (1997). Structure and evolution of the external basement massifs (Aar, Aiguilles Rouges/Mt. Blanc). In: Deep Structure of the Swiss Alps: Results from NFP 20, Birkhäuser Verlag Basel, 139-153.

Pleuger, J., Mancktelow, N., Zwingmann, H., \& Manser, M. (2012). $\mathrm{K}$-Ar dating of synkinematic clay gouges from Neoalpine faults of the Central, Western and Eastern Alps. Tectonophysics, 550, $1-16$.

Ramsay, J.G., Casey, M., Dietrich, D., Kligfield, R., Mancktelow, N., Schmid, S., Siddans, A.W.B., \& Pfiffner, A.O. (1981). Strain features of the Helvetic nappes of Switzerland. In: The Geological Society of America, 94th annual meeting 13. Abstracts with Programs-Geological Society of America, 535.

Ramsay, J. G., Casey, M., \& Kligfield, R. (1983). Role of shear in development of the Helvetic fold-thrust belt of Switzerland. Geology, 11, 43-442. 
Ramsay, J. G., \& Huber, M. I. (1983). The techniques of modern structural geology. Strain Analysis, 1.

Reinecker, J., Danišík, M., Schmid, C., Glotzbach, C., Rahn, M., Frisch, W., \& Spiegel, C. (2008). Tectonic control on the late stage exhumation of the Aar Massif (Switzerland): Constraints from apatite fission track and (U-Th)/He data. Tectonics, 27(6).

Sala, P., Pfiffner, O. A., \& Frehner, M. (2014). The Alpstein in three dimensions: fold-and-thrust belt visualization in the Helvetic zone, eastern Switzerland. Swiss Journal of Geosciences, 107, $177-195$.

Schardt, H. (1893). Sur l'origine des Prealpes romandes. Eclogae Geologicae Helvetiae, 4, 129-142.

Schaub, K. (1936). Geologie des Rawilgebietes. Eclogae Geologicae Helvetiae, 41, 89-94.

Scheiber, T., Adrian Pfiffner, O., \& Schreurs, G. (2013). Upper crustal deformation in continent-continent collision: a case study from the Bernard nappe complex (Valais, Switzerland). Tectonics, 32(5), 1320-1342.

Schmid, D. M., Aebli, H. R., \& Zingg, A. (1989). The role of the Periadriatic line in the tectonic evolution of the Alps. Geological Society, London, Special Publications, 45(1), 153-171.

Seward, D., \& Mancktelow, N. S. (1994). Neogene kinematics of the central and western Alps: evidence from fission-track dating. Geology, 22(9), 803-806.

Sperner, B., Ratschbacher, L., \& Ott, R. (1993). Fault-striae analysis: a turbo pascal program package for graphical presentation and reduced stress tensor calculation. Computers and Geosciences, 19(9), 1361-1388.

Steck, A. (1984). Structures de déformation tertiaires dans les Alpes centrales (transversale Aar-Simplon-Ossola). Eclogae Geologicae Helvetiae, 77, 55-100.

Steck, A., Bigioggero, B., Dal Piaz, G. V., Escher, A., Martinotti, G., \& Masson, H. (1999). Carte géologique des Alpes de Suisse occidentale, 1:100,000, Carte géologique spéciale No 123. Berne: Service Hydrologique et Géologique National.

Steck, A., Epard, J. L., Escher, A., Lehner, P., Marchant, R., Masson, H. (1997). Geological interpretation of the seismic profiles through Western Switzerland: Rawil (W1), Val d'Anniviers (W2), Mattertal (W3), Zmutt-Zermatt-Findelen (W4) and Val de Bagnes (W5). Deep Structure of the Swiss Alps: Results from NFP 20, Birkhäuser Verlag Basel, 123-138.

Sternai, P., Herman, F., Champagnac, J. D., Fox, M., Salcher, B., \& Willett, S. D. (2012). Pre-glacial topography of the European Alps. Geology, 40(12), 1067-1070.

Sue, C., Delacou, B., Champagnac, J.-D., Allanic, C., Tricart, P., \& Burkhard, M. (2007). Extensional neotectonics around the bend of the Western/Central Alps: an overview. Annual Review of Earth and Planetary Sciences, 96, 1001-1029.

Trümpy, R. (1960). Paleotectonic evolution of the central and western Alps. Geological Society of America Bulletin, 71, 843-908.

Trümpy, R. (1980). Geology of Switzerland: a guide book. Wepf and Company.

Ustaszewski, M., Hampel, A., \& Pfiffner, O. A. (2008). Composite faults in the Swiss Alps formed by the interplay of tectonics, gravitation and post-glacial rebound: an integrated field and modelling study. Swiss Journal of Geosciences, 101(1), 223-235. doi:10.1007/s00015-008-1249-1.

Ustaszewski, M., McClymont, A., Herwegh, M., Preusser, F., \& Pfiffner, O. A. (2007). Unravelling the evolution of an Alpine to post-glacially active fault in the Swiss Alps. Journal of Structural Geology, 29-12, 1943-1959. doi:10.1016/j.jsg.2007. 09.006 .

Ustaszewski, M. \& Pfiffner, O.A. (2008). Neotectonic faulting, uplift and seismicity in the central and western Swiss Alps. In: Siegesmund, S., Fuegenschuh, B. \& Froitzheim, N. (eds) Tectonic Aspects of the Alpine-Dinaride-Carpathian System. Geological Society, London, Special Publications, 298, 231-249. doi:10.1144/SP298.12.

Vernon, A. J., Van Der Beek, P. A., Sinclair, H. D., \& Rahn, M. K. (2008). Increase in late Neogene denudation of the European Alps confirmed by analysis of a fission-track thermochronology database. Earth and Planetary Science Letters, 270(3), 316-329. 